\title{
Tsunami evacuation times and routes to safe zones: a GIS-based approach to tsunami evacuation planning on the island of Stromboli, Italy
}

Emmie M. Bonilauri ${ }^{1} \mathbb{B}$, Andrew J. L. Harris ${ }^{1 *}$, Julie Morin ${ }^{1,2}$, Maurizio Ripepe ${ }^{3}$, Domenico Mangione ${ }^{4}$, Giorgio Lacanna ${ }^{3}$, Stefano Ciolli ${ }^{4}$, Maria Cusolito ${ }^{5}$ and Pauline Deguy ${ }^{6}$

\begin{abstract}
While a landslide at the volcanic island of Stromboli (Aeolian Islands, Italy) in December 2002 created a tsunami with a run-up of $10.9 \mathrm{~m}$, two paroxysmal eruptions in the summer of 2019 caused a tsunami with an amplitude of 40 to $20 \mathrm{~cm}$. All three events required rapid, spontaneous emergency evacuations of the beach zone as the time between tsunami generation and impact is around $4 \mathrm{~min}$. These conditions thus require a special consideration of the issue of evacuation capabilities on the island in the event of a volcanogenic tsunami. The purpose of this paper is thus to (i) determine pedestrian evacuation times from high-risk coastal areas to safe zones, (ii) to assess building evacuation ease, and (iii) determine emergency evacuation plans (for buildings and coastal zones). For this purpose, we created a GIS-based risk analysis/mapping tool that also allowed macroscopic evacuation modelling. In our case, the high-risk zone to be evacuated involves an area extending to $10 \mathrm{~m}$ a.s.l. and involving 123 individual buildings over an area of $0.18 \mathrm{~km}^{2}$. The results show that $33 \%$ of the buildings can be evacuated in $4 \mathrm{~min}$, and that a 10-min warning time is required for a complete and well-distributed evacuation whereby the population is evenly distributed between all evacuation exits to avoid the potential for congestion. Initial interviews of residents in the at-risk zone reveal a high level of awareness and a desire for personalized evacuation scenarios.
\end{abstract}

Keywords: Stromboli, Volcanogenic tsunami, Volcanic island hazard, Evacuation modelling, Evacuation maps

\section{Introduction}

All international tsunami risk management bodies agree that planning for evacuation drastically reduces the risk and saves lives among coastal populations (Scheer et al. 2011; FEMA 2019). Evacuation plans allow for effective placement of signs indicating danger zones, refuge sites, and evacuation routes (Dall'Osso and Dominey-Howes 2010; FEMA 2019) and can be used to support increased public

\footnotetext{
* Correspondence: Andrew.HARRIS@uca.fr

'Université Clermont Auvergne, CNRS, IRD, OPGC, Laboratoire Magmas et Volcans, Clermont - Ferrand, France

Full list of author information is available at the end of the article
}

awareness, which will help to develop reflexes and resilience of coastal populations (Gregg et al. 2006; Kelman et al. 2008; Morin et al. 2008; Løvholt et al. 2019; Wood et al. 2019), improving the efficiency of future evacuations (Péroche 2016). A number of studies have been carried out around the world to reduce the impact of tsunamis on populations by increasing the efficiency of evacuations through planning (Lämmel et al. 2010; Sahal 2011; Leone et al. 2013, 2014, 2018; Péroche et al. 2014; Péroche 2016). What all of these studies show is that an effective evacuation has to be based on a viable plan that takes into account the physical state of evacuation routes 
(widths of roads/paths, surface type, state of repair, slope) and the speed at which the population in need of evacuation can move from the danger zone to the refuge site (cf. Leone et al. 2018).

Two types of evacuation can be considered: horizontal evacuation, where exposed populations are moved out of the danger zone, and vertical evacuation, where populations seek safety by gaining a high point within the danger zone, which may include specially designed and constructed towers, i.e., vertical evacuation shelters (e.g., Nakano 2010; Park et al. 2012; Ashar et al. 2014). In the case of a horizontal evacuation, several modes of transportation can be used: personal vehicle, public transport and/or by foot (Péroche 2016). To implement either a horizontal or vertical evacuation, the quickest most efficient route between the point to be evacuated and the security zone needs to be defined (cf. Forcael et al. 2014), as does the viability of that route for evacuation (e.g., Hamacher and Tjandra 2001; Daamen and Hoogendoorn 2010; Lämmel et al. 2010). There are two categories of models for simulating mass evacuation: microscopic and macroscopic. Microscopic models (e.g. multi-agent models) are used to simulate human behaviour and interactions between individuals essentially on a local scale. These models are mainly used for evacuation through individual doors, corridors or rooms, and apply to single buildings, shopping malls or ships (e.g., Daamen and Hoogendoorn 2010; Jo et al. 2014; Wang et al. 2014). In contrast, macroscopic models can be used at a smaller spatial scale to obtain theoretical values of evacuation time or capacity using graph theory for entire cities or city blocks (Leone et al. 2013). The first step of an evacuation planning approach based on macroscopic modelling is to collect as much information as possible on the tsunami risk in the target area (Scheer et al. 2011; FEMA 2019). Fundamental to this is a definition of the exposed area, i.e., the area likely to be flooded by the tsunami and thus in need of evacuation, and a safe "refuge" area (cf. Leone et al. 2018; Fig. 1). Such scenarios can be based on past events that have been recorded and whose run-up limits have been mapped or hazard modelling (e.g., Tinti et al. 2006a;

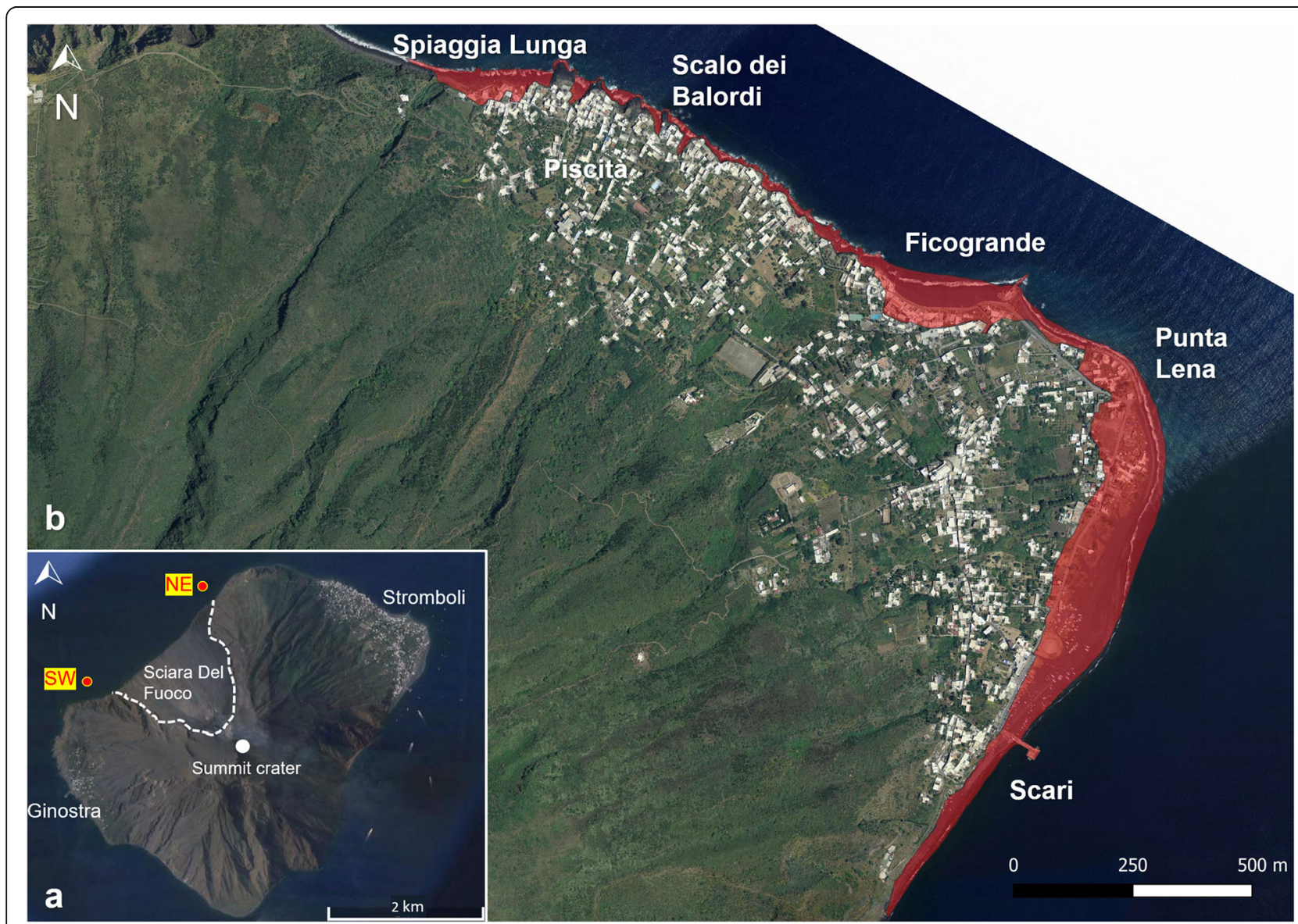

Fig. 1 a Map of Stromboli with the location of Stromboli and Ginostra villages, the Sciara del Fuoco and the two sea floor tsunami sensors located to the Northeast (NE) and Southwest (SW) of the Sciara del Fuoco. b Map of Stromboli zoomed on the zone impacted by 2002-tsunami. Image data (2019 Google Earth: SIO, NOAA, U. S. Navy, NGA, GEBCO 

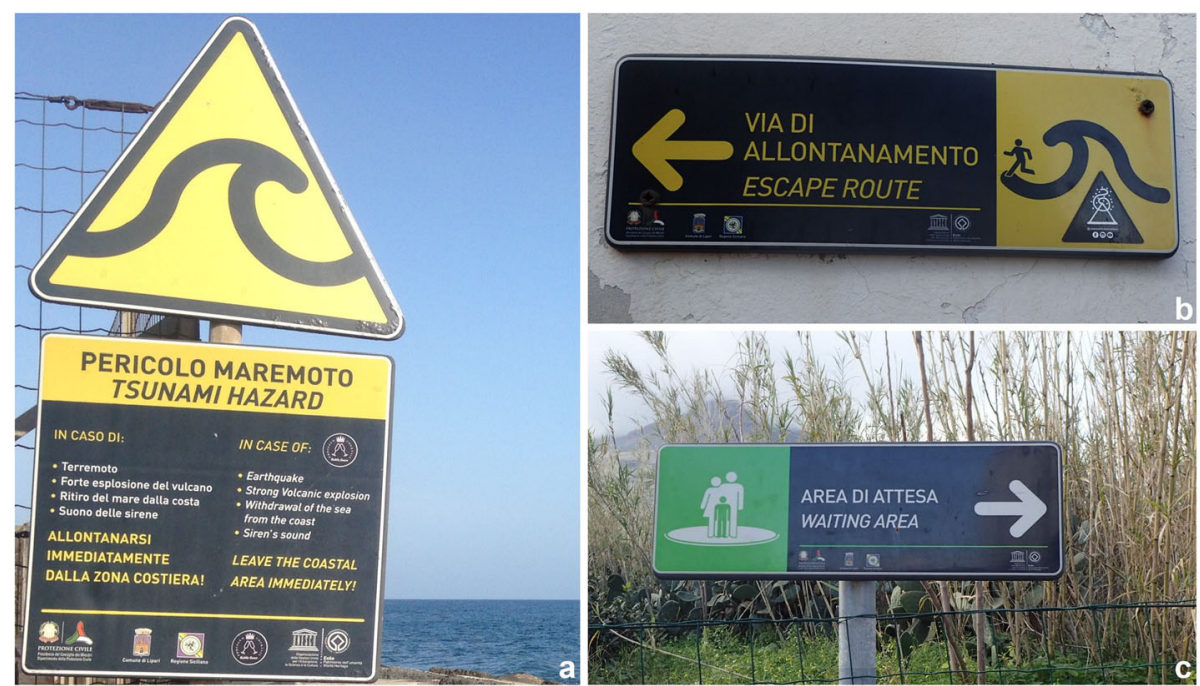

Fig. 2 Tsunami signage related to hazard zone, evacuation route and safe area (UNESCO standardised design). a Sign on Stromboli Island designating the area as a Tsunami Hazard zone, but also indicating other important elements, including the expected behavioural response (i.e., to leave the coastal area immediately) "in case of" several sources of early alert (i.e., environmental cues/natural warnings and sirens sounding). $\mathbf{b}$ "Escape route" direction arrows. c Signage with arrow indicating the direction to waiting areas

Giachetti et al. 2012; Fraser et al. 2014; Paris et al. 2017). A safety margin should be added between the area likely to be flooded and the refuge area to guarantee the safety of individuals in the event of extreme events (Péroche 2016), where Leone et al. (2018) in their EXPLOIT method advise a safety margin of at least $5 \mathrm{~m}$ above the maximum run-up recorded. Placement of such an error margin is consistent with the findings of Smart et al. (2016) who point out that initial waves can smooth the micro-topography to increase the run ups of subsequent waves. Then, through fieldwork, data has to be collected on the number of people to be evacuated, the points from which they need to be evacuated, the areas to which they should be evacuated, and the characteristics and qualities of the paths used for transit between each evacuation point and refuge area (Weidmann et al. 2014; Leone et al. 2018). Then, simulations are run to find the quickest, most efficient, evacuation routes. We here develop just such a method, based on the models of Péroche (2016) and Leone et al. (2018), to assess best horizontal pedestrian evacuation from a populated shoreline in the event of a locally-induced volcanogenic tsunami for which there is little response time.

We focus our study on the island of Stromboli (Aeolian Islands, Italy) for three reasons. First, Stromboli has been the site of several locally-triggered tsunamis over the last 100 years, either triggered by landslides or pyroclastic flows entering the sea (Maramai et al. 2005a; Tinti et al. 2006a). The distance between the source of the tsunami (at the foot of the Sciara del Fuoco) and the shore-line population (between the villages of Piscità and Scari) is just a few kilometres, so that tsunami travel times to the exposed population is very short, being just a few minutes (Tinti et al. 2006b). Second, a mixed population of tourists and local residents populate the shoreline in differing densities between summer and winter. Each population will have differing levels of understanding, education and, hence, evacuation needs (Johnston et al. 2016; Blake et al. 2018). Third, a warning system is in place on Stromboli involving a siren system triggered by a sea-floor pressure sensor (Bertolaso et al. 2009; Lacanna and Ripepe 2020). This warning system has been coupled with installation of signage on the island indicating "escape routes" between the zone to be evacuated and refuge zones (Fig. 2). Note that in this study we use "evacuation routes" rather than "escape routes" to conform to the international standards established in terms of tsunami evacuation (International Tsunami Information Center 2021). However, events of 2019 when a paroxysmal explosion triggered a pyroclastic flow that entered the sea to generate a tsunami highlighted a need to update the evacuation plans and produce maps showing optimum evacuation routes. Fundamentally, a confused response was observed, with some tourists actually jumping into the sea (Rai News 2019). ${ }^{1}$ Confused responses were also observed in Greece and Turkey during the tsunami of 2017 (Løvholt et al. 2019). Locally the objective of this work is thus: (i) to determine pedestrian evacuation times from coastal areas, (ii) to assess the ease with which one can evacuate

${ }^{1}$ Alcuni dei turisti per paura si sono lanciati in mare - Some of the tourists out of fear jumped into the sea (following the 3 July explosion). 
a building, (iii) to design emergency evacuation plans (for buildings as well as open-space coastal zones) tailored to the needs of permanent residents and visitors, as well as hotel owners, vacation rentals, restaurants and shops. Crucially, given estimated evacuation times, we need to know the minimum alert time to allow all atrisk areas to be evacuated before wave arrival. In doing this, we define a Geographical Information System (GIS) based methodology to generate both large scale and individual building evacuation plans for any similar scenario.

\section{Setting}

The island of Stromboli is the emerged part of a large submarine volcano that began building $100 \mathrm{ka}$ (HornigKjarsgaard et al. 1993). The summit of the island reaches $924 \mathrm{~m}$ above sea level (a.s.l.), while the submarine base of the volcano is at a depth of $2000 \mathrm{~m}$ below sea level (b.s.l.) (Hornig-Kjarsgaard et al. 1993; Pasquarè et al. 1993). The morphology of Stromboli volcano has evolved over time during nine cycles of activity, each associated with flank collapse. The last major collapse was $5 \mathrm{ka}$ and is the origin of the Sciara del Fuoco (HornigKjarsgaard et al. 1993; Pasquarè et al. 1993; Tibaldi 2001; Corazzato et al. 2008; Fig. 1). Current hazards at Stromboli can be grouped into five main classes (Barberi et al. 1993), those associated with: (i) normal explosive activity, (ii) major explosions, (iii) paroxysmal crises feeding ash plumes to $\geq 4 \mathrm{~km}$ and pyroclastic density currents (PDCs) to the sea, (iv) lava flows and (v) subaerial and submarine landslides. Hazard classes (iii) and (v) are associated with tsunamis, as arrival of large volumes of material (either as a PDC or landslide) into the sea produces a mass displacement of the water to produce tsunamis with run ups of up to $10.9 \mathrm{~m}$ (Tinti et al. 2006a).

Tsunami worst-case scenarios at Stromboli envisage a total collapse of the Sciara del Fuoco, just as when it was formed $5 \mathrm{ka}$ (Kokelaar and Romagnoli 1995; Tinti et al. 2000). The 5-ka collapse involved a volume of material of between 0.97 and $1.81 \mathrm{~km}^{3}$ (Kokelaar and Romagnoli 1995), and the resulting tsunami would have had a runup of up to $50 \mathrm{~m}$ (Tinti et al. 2000). Another scenario would be a seismically generated tsunami. The tsunami generated by the $1908 \mathrm{M}_{\mathrm{W}} 7.1-7.3$ earthquake and associated submarine landslide that occurred in the Straits of Messina had a run-up of up to $11.7 \mathrm{~m}$ (Tinti and Armigliato 2003; Favalli et al. 2009). However, Italian Civil Protection is preparing for a less catastrophic, but more likely and manageable (plausible) scenario, based on historical tsunamis of a local, on island or submarine flank source, that have impacted Stromboli in the past due to PDCs or landslides displacing the sea (Maramai et al. 2005a). The 2002 and 2019 tsunamis, respectively resulting from landslide and PDC entry into the sea, are thus currently used by Civil Protection as an evacuation scenario. This seems realistic for the most likely events in need of evacuation, where other tsunamis with such triggers occurred in 1916, 1919, 1930, 1944, 1954, and 1988 (Maramai et al. 2005a; Roberto et al. 2014). However, these events either had a smaller amplitude or lack data. The 1930 tsunami is known, though, to have had a runup of 2-3 m (Maramai et al. 2005a). We thus next detail these two tsunami case types that we will use to define the exposed area and evacuation times in our evacuation system.

On December 28, 2002, after several months of high levels of normal explosive activity, a flank eruption began on the Sciara del Fuoco (Bonaccorso et al. 2003; Calvari et al. 2005). Two days later on December 30 two landslides occurred on the Sciara del Fuoco, the first at 13:15 (local time) and the second at 13:22. They generated two tsunamis $7 \mathrm{~min}$ apart, each with a maximum run-up of $10.9 \mathrm{~m}$ (Tinti et al. 2006a). The first tsunami was due, in a large part, to a submarine landslide near the coast, which involved $20 \times 10^{6} \mathrm{~m}^{3}$ of material (Chiocci et al. 2003). The second tsunami was caused by a purely sub-aerial landslide that broke off at about 500 $\mathrm{m}$ a.s.l and involved a volume of material of between 4 and $9 \times 10^{6} \mathrm{~m}^{3}$ (Tinti et al. 2006b). The run-up area, given in Fig. 1, was obtained from post-event surveys made along the coasts of the Aeolian Islands (Maramai et al. 2005b; Tinti et al. 2006a). According to eye-witness testimonies the first tsunami was particularly destructive in Ficogrande and along the Spiaggia Lunga Beach, as located in Fig. 3 (Tinti et al., 2005). Both tsunamis were also said to have caused light damage in Scari, also located in Fig. 3. On Stromboli, many houses are located along the seafront and are particularly exposed to the tsunami hazard (Fig. 4). Following the landslides, the entire coastline of the island was affected by tsunamis in less than $4 \mathrm{~min}$ (Tinti et al. 2006b). The waves moved faster in the deeper water and reached the island of Panarea, $20 \mathrm{~km} \mathrm{SW}$ of Stromboli, in just under $5 \mathrm{~min}$ (Tinti et al. 2006b).

On July 3 and August 28, 2019, two paroxysms occurred each producing an ash plume several kilometres in height and pyroclastic flows that entered the sea (Global Volcanism Program 2019). Seafloor pressure sensors run by the LGS (Laboratorio Geofisica Sperimentale - Università di Firenze, Florence, Italy) recorded a tsunami with an amplitude of 40 to $20 \mathrm{~cm}$. The sensors are linked to a siren-based warning system in the village of Stromboli and on August 28, the sirens were triggered manually $15 \mathrm{~s}$ after wave generation and $75 \mathrm{~s}$ after the explosion (Lacanna and Ripepe in prep). Response by tourists, who at the time were arriving on day excursion boats from the mainland (mostly the towns of Tropea and Messina), as well as those on the beaches, was confused. Many ran towards the sea, away from the eruption 


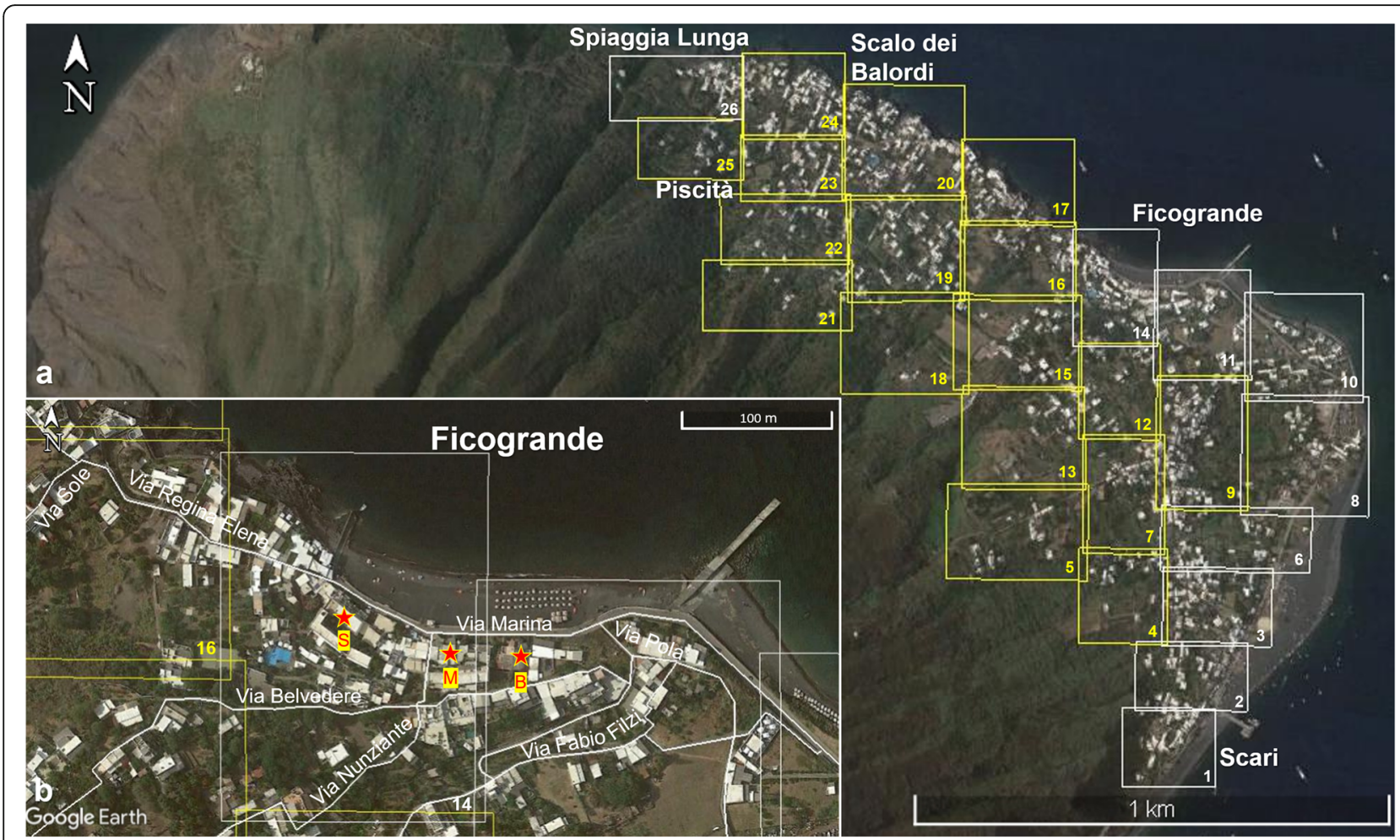

Fig. 3 a Zoom on Stromboli village with the delimitation of the inhabited areas (in white, the squares mapped during fieldwork). $\mathbf{b}$ Zoom on Ficogrande with the local road network and location of the two main hotels: The Sirenetta Park (S) and Miramare (M), as well as building 025B (B) described in Appendix A. Image data @2019 Google Earth: SIO, NOAA, U. S. Navy, NGA, GEBCO

but towards the eventual in-coming tsunami. At the harbour, tourists tried to reboard the vessels they had just disembarked, and in the confusion, some found themselves on the wrong boat and returned to Messina rather than Tropea. This argues for the need for a well-stated evacuation plan supported by clearly marked evacuation routes and safe locations.

\section{Method}

GIS layers listed in Table 1 were already available from the European Space Agency (ESA), LGS, and the Dipartimento della Protezione Civile (DPC). This included a Digital Elevation Model (DEM), a Pleiades-1A image on which all buildings could be identified, located and their shapes mapped, as well as the area in need of evacuation

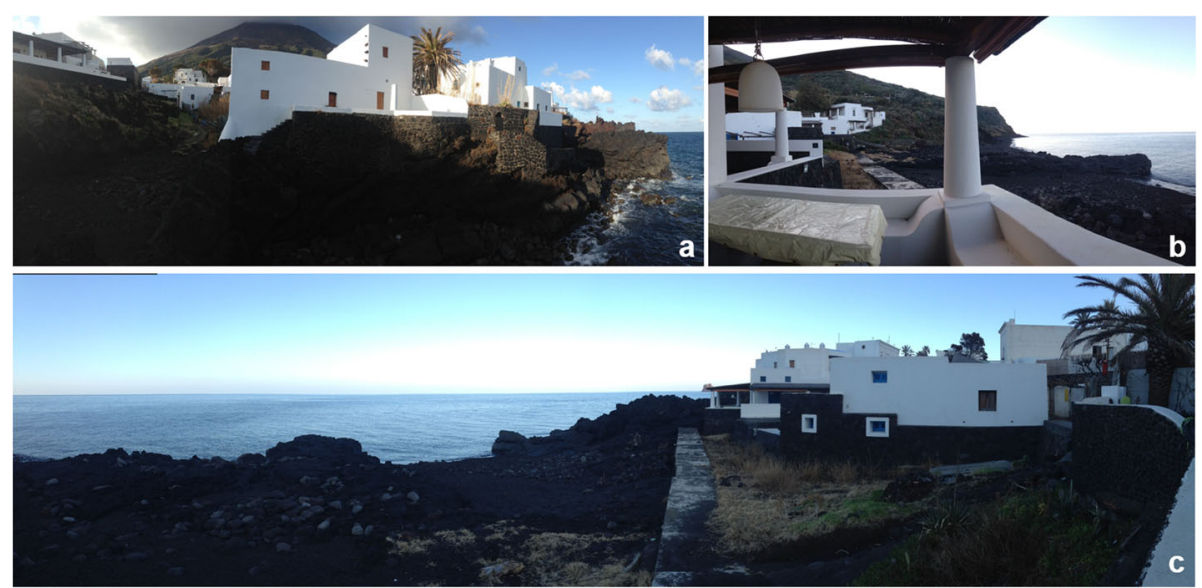

Fig. 4 Typical strombolian buildings in front of the sea. a View looking north along the sea front showing holiday homes on top of a $5 \mathrm{~m}$ high lava cliff at Scalo dei Balordi. $\mathbf{b}$ View looking north from balcony in house at the SE end of Spiaggia Lunga towards the tsunami source. $\mathbf{c}$ View looking east along the sea front at Spiaggia Lunga 
Table 1 Existing GIS layers from ESA, LGS and DPC

\begin{tabular}{|c|c|}
\hline Objects & Data creation dates \\
\hline Pleiades-1A image & June 14, 2019 (0.5 m resolution) \\
\hline $\begin{array}{l}\text { Digital Elevation Model (DEM), Digital Surface Model (DSM), Digital Terrain } \\
\text { Model (DTM) }\end{array}$ & $\begin{array}{l}\text { DEM: September 2017; DSM: February 2014; } \\
\text { DTM: January } 2014\end{array}$ \\
\hline $\begin{array}{l}\text { Area impacted by the } 2002 \text { tsunami, Operational centres, Sirens, } 400 \text { m } \\
\text { contour line, Helicopter landing pad, Waiting areas, Streets, Evacuation } \\
\text { routes }\end{array}$ & $\begin{array}{l}\text { Area impacted by the } 2002 \text { tsunami: August 2010; Operational centres: } \\
\text { June 2014; Sirens: February 2003; } 400 \text { m contour line: July 2006; } \\
\text { Helicopter landing pads: February 2014; Waiting areas: April 2010; } \\
\text { Streets: July 2010; Evacuation routes: July } 2010\end{array}$ \\
\hline
\end{tabular}

(the "red" zone) as defined by DPC based on the December 2002 run-up data. However, several layers, including building exit points, open spaces, beaches, "safe" zones, and road/path networks needed to be created. This was done by mapping the village during a 10-day field survey in January 2020. Prior to field work, the village area was divided into 26 map squares to be surveyed using Google Earth and the Pleiades imagery (Fig. 3). To assess the tsunami hazard, areas impacted by the 2002 run-up were focused on (i.e., mapping squares $1,2,3,6,8,10,11,14$ and 26 in Fig. 3). During the survey, the physical characteristics of each building in the targeted map squares were recorded (Appendix A), photos were taken (Appendix B), and each building was assigned a unique code. The road network was segmented, assigned a code and the character (surface type, state of repair, width, bottlenecks, number of steps, presence of street furniture/ drains) described. All buildings and road segments were mapped on hardcopy map sheets (one for each square), and a custom designed data sheet was filled out for each building (e.g., Appendix A). Thus, during fieldwork, 14 extra vector layers were created (Table 2) to complement those already available as listed in Table 1. Data were integrated into a GIS where we used QGIS (Quantum GIS) 3.10 .3 with GRASS (Geographic Resources Analysis Support System) version 7.8.2. The projected CRS (Coordinate Reference System) used was WGS 84 / UTM zone $33 \mathrm{~N}$, as is suitable for use in the Northern hemisphere between the equator and $84^{\circ} \mathrm{N}$, and between $12^{\circ} \mathrm{E}$ and $18^{\circ} \mathrm{E}$ (EPSG database,2019). This GIS was set up in a five step process to allow generation of the key product: an evacuation route map and evacuation time matrix (Fig. 5).

\section{Step 1: Evacuation area delineation}

We considered two tsunami hazard scenarios triggered locally by volcanic activity. The first scenario is a landslide trigger, which has a sudden onset, such as the events of 2002. The sudden and local trigger means that there is just a 4-min travel time for the wave from the source of the tsunami (the foot of the Sciara del Fuoco) to Stromboli village (Fig. 1). The second scenario is entry of pyroclastic flow into the sea during a paroxysm and the tiltmeters on which is based the actual warning system gives a 3-4-min tsunami travel time. We thus needed to define three zones using the polygon vector layers of the DEM (Fig. 5a): a four-minute evacuation zone; a margin of error zone, and a "safe" zone. Because each zone is delineated by an altitude level, to construct these areas it was first necessary to extract the contours from the DTM, where a step of $5 \mathrm{~m}$ between each curve was used based on the $10.9 \mathrm{~m}$ run-up of 2002 (Tinti et al. 2006a) plus $5 \mathrm{~m}$ of associated uncertainty (Leone et al. 2018). The red zone represents the area to be evacuated in the case of a December 2002-type event for which we have $4 \mathrm{~min}$ of warning. This zone corresponds to the area impacted by the 2002 tsunami and roughly follows the $10 \mathrm{~m}$ contour. The yellow zone is the possible error margin and is located between the red zone and the $15 \mathrm{~m}$ contour. The green zone is the "safe" zone and starts above the $15 \mathrm{~m}$ contour.

\section{Step 2: High-stakes areas}

A high-stakes area was defined as including all buildings of the red zone. These were analysed in detail because of their high exposure in the case of future tsunami. To do this, a field survey sheet was designed to assess the ease of escape from a room, building or property including location and size of windows and doors by storey, ease of roof access, presence of shutters and type, and presence of gates and steps (Appendix A). Building evacuation exits were categorised as single door, which can accommodate one person at a time and double door which can take two people at a time (cf. Daamen and

Table 2 Data layers created on QGIS. RAEP is Refuge Area Entry Point

\begin{tabular}{ll}
\hline Layers & Objects \\
\hline Polygon vector layers & Buildings, Open spaces, Beaches, Green zone, Yellow zone, People-Populated starting grid \\
Line vector layers & Road network, Contour lines of $10 \mathrm{~m}, 15 \mathrm{~m}$, and $20 \mathrm{~m}$ \\
Points vectors layers & RAEP, Escape route panels, Waiting area panels, Tsunami hazard panels \\
\hline
\end{tabular}




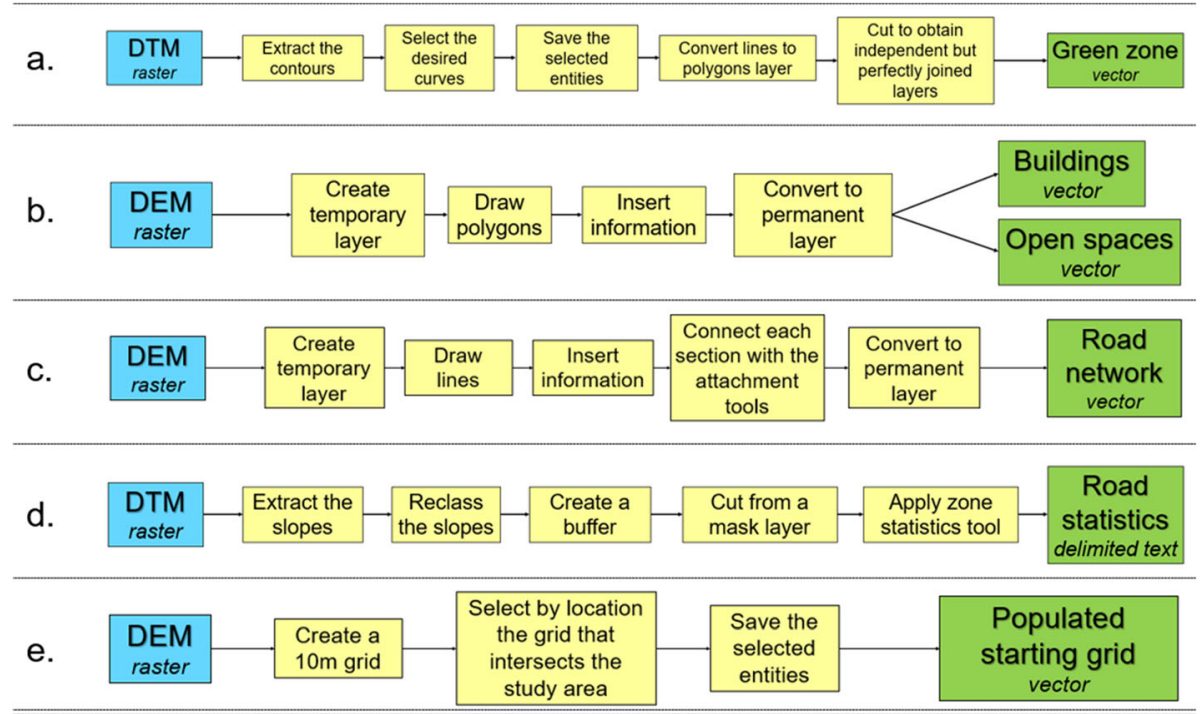

Fig. 5 a Extraction steps of contour lines and creation of different zones. $\mathbf{b}$ Creation steps for building, open space, and beach zone data. c Creation steps for the road network. $\mathbf{d}$ Extraction of slopes. e Creation steps of the populated starting grid. Blue $=$ initial data, Yellow $=$ data processing steps, and Green = generated "data" layer (modified from Leone et al. 2018)

Hoogendoorn 2010; Jo et al. 2014). The use of ground floor windows can be considered as a last resort for evacuation, where we distinguished between very small windows (that cannot be used), single windows (one person) and double windows (two people). The height of building enclosure walls was also recorded to determine if it was possible to climb over it and evacuate more quickly. An example of a completed survey is given in Appendix A. Survey sheets were completed for all 123 buildings in the red zone and archived for future update. Open spaces in the high-stakes area were also mapped, as such open spaces will contain many movable (unanchored) objects such as boats, containers or building material. In the event of a tsunami, such objects can be picked up by the tsunami to become projectiles capable of inflicting further damage on buildings and shelters. They also represent an additional hazard, as well as obstacle, to the population during an evacuation. All data collected for buildings and open spaces, including beach areas, were then entered into QGIS as polygon vector layers with the DEM as the base layer (Fig. 5b).

\section{Step 3: Road network construction}

The road and path network must be well mapped and described to implement the most accurate evacuation time calculations as possible. This is especially important given our four-minute evacuation time. Thus, during field work the roads were separated into segments defined by surface type, minimum width and state of repair (pot holes, open drains, collapsed walls), as well as the presence of obstacles (such as concrete bollards and lamp posts) and gates (including whether they were locked or not, private or public). The vector layer of the road network was then created with a series of polylines (Fig. 5c). A road network must be a single segment, thus the individual road segments had to be properly linked to each other using the attachment tool of QGIS. A lack of attachment in any one place will prevent the passage of evacuees to the safe area in the simulation. To ensure a perfectly united network, we used the network provided by Open Street Map plugin on QGIS and added the missing segments.

A tsunami evacuation commonly involves a positive change in elevation. It is, therefore, also necessary to estimate evacuation speed according to the slope of the terrain (Péroche 2016). Indeed, a steeper slope will reduce evacuation speed and more time will be needed to reach the green ("safe") zone. To do this, slope values were extracted from the DTM (Fig. 5d) using the GDAL (Geospatial Data Abstraction Library) tool in the Toolbox of QGIS. Slope values were then reclassified using the "r.reclass" tool of the GRASS software integrated into QGIS. Following the 10 slope-dependant evacuation velocity classes and weightings of Péroche (2016), 10 slope classes were defined (Table 3).

Once the slopes were classified, the "statistical" tool of QGIS was used to calculate the average slope value for each road section. The average speed adopted by evacuees is referred to as the "constrained average speed" because it is influenced by the imminence of danger (Péroche 2016). That is, it is faster than normal as the evacuee is aware of the danger and the need to evacuate. However, the speed will still vary according to the class of slope and the nature of the road section (Table 3). 
Table 3 Pedestrian evacuation speeds adopted and weightings (translated and modified from Péroche 2016)

\begin{tabular}{|c|c|c|c|c|c|}
\hline \multirow[b]{2}{*}{ Class } & \multirow[b]{2}{*}{ Slope value (\%) } & \multirow[b]{2}{*}{$\begin{array}{l}\text { Associated speed } \\
(\mathrm{km} / \mathrm{h})\end{array}$} & \multicolumn{3}{|c|}{ Speeds after application of reduction coefficient $(\mathrm{km} / \mathrm{h})$} \\
\hline & & & Two-lane road & Single-lane road & Passageway, path, stairs, unsurfaced track \\
\hline Reduction coefficient & & & 1 & 0.8 & 0.5 \\
\hline 1 & $<3$ & 4.85 & 4.85 & 3.88 & 2.43 \\
\hline 2 & {$[3-6[$} & 4.55 & 4.55 & 3.64 & 2.28 \\
\hline 3 & {$[6-9[$} & 4.26 & 4.26 & 3.41 & 2.13 \\
\hline 4 & {$[9-12[$} & 3.97 & 3.97 & 3.18 & 1.99 \\
\hline 5 & {$[12-15[$} & 3.69 & 3.69 & 2.95 & 1.85 \\
\hline 6 & [15-18[ & 3.42 & 3.42 & 2.74 & 1.71 \\
\hline 7 & [18-21[ & 3.15 & 3.15 & 2.52 & 1.58 \\
\hline 8 & {$[21-24[$} & 2.90 & 2.90 & 2.32 & 1.45 \\
\hline 9 & [24-27[ & 2.65 & 2.65 & 2.12 & 1.33 \\
\hline 10 & $\geq 27$ & 1.71 & 1.71 & 1.37 & 0.86 \\
\hline
\end{tabular}

Thus, road sections were classified into three categories according to their nature: a first class includes two-lane roads, a second class includes single-lane roads, and a last class includes narrow passageways, alleys, paths, stairs, and tracks/trails. Each section type was then assigned a speed reduction coefficient (Table 3). Evacuation time calibration was carried out by us at Ficogrande (Fig. 3) by walking and running from starting points in the red zone to safe zones, where evacuations were guided (i.e., the evacuation route was known) and unguided (i.e., the route was not known). These were used to compare with our simulated routes and times.

\section{Step 4: Number of evacuees (network load)}

To assess the load on the evacuation network in terms of congestion, the likely number of escapees needs to be assessed. Two types of evacuation scenario were considered for the red zone: an individual evacuation of each building and a large-scale evacuation of tourist gathering places (hotels, beaches, sea front restaurants, bars, and shops). To test a mass evacuation, a populated starting grid must be created in the form of a polygon-type vector layer. To do this, we found that a square grid with $10 \mathrm{~m}$ cell sizes with a coverage corresponding to the red zone was optimal (Fig. 5e). For each square in the grid, a population density now needs to be estimated. This was achieved through holiday apartment rental ads and hotel capacities as advertised on the Internet (room capacities for hotels can, for example, be obtained from booking websites). If such information was not available, we used a density of one person per $20 \mathrm{~m}^{2}$, a value calculated from the Internet-derived data. For the beach, the density was estimated by head counts from 85 photos between 2012 and 2019 available on Google Images.

For each population grid square, a centroid is automatically created with the "centroids" tool of QGIS.
These centroids represent the starting points of each evacuation and contain the density information of the populated starting grid. Some of these centroids had to be moved to correspond to the exit of a building. All centroids must be attached to the road network using the attachment tool. After the 2002 tsunami, road signs were installed to inform or to indicate evacuation routes (Fig. 2). Three sign layers were thus also created in the GIS: tsunami hazard information panels, "escape route" arrows, and waiting area signs (Table 2). To reach the green zone, evacuees must pass through a Refuge Area Entry Point (RAEP). RAEPs are present at the intersection of the road network and the $20 \mathrm{~m}$ contour line, i.e., the entry of the evacuation route into the green zone. Following Leone et al. (2018) the entrance into the refuge zone was thus shifted $5 \mathrm{~m}$ in height into the green zone to prevent evacuees from stopping exactly at the boundary between the safe zone and the danger zone to present a bottle neck (cf. Ma et al. 2014).

\section{Step 5: Evacuation simulation calibration}

Evacuation time calculations were made from all departure points, the centroids, to all red zone evacuation exits, the RAEPs. These simulations in QGIS are carried out with the QNEAT3 plugin (Médard and Foulquier in prep). The simulations need: (i) a road network (polyline vector layer), (ii) a populated starting grid (polygon vector layer), (iii) origin points (polygon centroid vector layer), (iv) destination points (point vector layer), and (v) a map background (raster layer). As part of the simulation, first, the road network is fragmented into segments with the "explode line" tool. Then, the "OD Matrix from Layers as Table (m:n)" tool of QNEAT3 is used to calculate the cost of each displacement on the road network from point $\mathrm{A}$ to point $\mathrm{B}$. The cost is defined as the required travel time to reach safety. Our focus is on the 
fastest times, so we used the fastest path criterion. The speed criteria defined as part of step 3 are inserted into the calculations as a velocity field and, because each road section has a speed value, the default speed does not need to be considered.

The result of the costing algorithm can be extracted using "DB Manager" in QGIS. In this way, the fastest travel times can be selected and saved as a new layer. Once the "fastest destination" layer has been created, the "Join attributes by field value" and the "Join by lines (hub lines)" tool allows generation of the paths between the departure points and the arrival points. However, these paths are "as the crow flies" and do not consider the road network. To modify the path, the "shortest path (layer to point)" tool makes it possible to draw paths as a function of the existing road network from the starting points layer to a RAEP. This adjustment is intended for a single, specific RAEP. Because we need to calculate the shortest evacuation times by considering all possible RAEPs, and so as to obtain a view of all the fastest paths, the Python console is instead set-up for all starting points and all arrival points. This Python script is available in the QNEAT3 tutorial (Médard and Foulquier in prep), where some small modifications must be made to the script, especially relating to the differences in the names of the layers used. Once the script is complete, each evacuation route is created in an individual layer named "Shortest Path Layer". This layer needs to be merged with all other shortest path layers with the "Merge vector layers" tool in QGIS to obtain a single layer with all the fastest evacuation routes.

\section{Interviews and fieldwork timing}

On-site, semi-structured interviews were conducted with residents. We sought to find out their experiences, needs, expectations, and reactions (positive or negative) to a tsunami on Stromboli. The interviews also allowed us to verify the limits of the 2002 inundation zone through eye-witness testimony. The field study was carried out at the end of January 2020, which is an extremely low tourist season. However, this had four advantages. First, the vast majority of buildings were unoccupied and therefore easy to access, with the population knowing that we were entering properties to complete a survey. Second, the population was "relaxed" (not preoccupied and stressed by the busy tourist season) and were thus able to help, actively supporting the project and devoting time to interviews. This was helped by a feeling that we were carrying out work to help them. Third, plans could be tailored to individual needs, especially for those living and working in the red zone. Fourth, we could get a good feel for the day and night use and permanent resident population density of the red zone, allowing us to design a plan useful for the permanent population who, given that they are always on the island, are the most exposed.

\section{Results}

Because our initial objective is to set-up, fine tune and test the methodology, we focused on a single control zone which contained all key elements of the evacuation scenario, and which is representative of the GIS content for the entire risk zone. For this, the area around the Ficogrande beach was chosen (Fig. 3). This area was particularly severely affected by the December 2002 tsunami, where water and entrained debris reached a height of $10 \mathrm{~m}$ along this stretch of coast causing heavy material damage to buildings (Tinti et al. 2006a). The topography is also extremely impractical in terms of evacuation, where a flat zone just $5 \mathrm{~m}$ wide is backed by a $12 \mathrm{~m}$ high cliff represented by a lava flow front, that of the San Bartolo unit emplaced during Stromboli's last flank eruption $5 \mathrm{ka}$ (Calvari et al. 2011). Because most of the village is underlain by such units (Calvari et al. 2011), such a topographic configuration is common along this coastline. This means that evacuation is either up a steep hill (or a flight of steps that ascend the flow front), or involves following the coast road so that evacuation is parallel to the shore for some distance. Fortunately, the 2002 tsunami took place in December, so the area was particularly empty.

Our January 2020 survey showed none of the buildings in the Ficogrande sector to be occupied during the winter, and a maximum daytime transient population of between one and three (this being workers maintaining the sea-front hotel gardens, fishermen on the jetty to the south of the area, or people passing through the sector on the coast road by bike or Ape-a small three wheeled moped-truck suitable for transport of freight through the narrow alleyways of Stromboli village). However, in the summer, the many holiday rentals and two hotels that characterize the land use of this zone are open, and by day the seaside restaurants are also open and full. Ficogrande also represents a popular tourist beach, and during any summer night the density estimate based on rental ads on the Internet shows that 400-500 people can be accommodated in this area.

All three hazard areas occupy this sector: red, yellow, and green (Fig. 6). Of these, the red zone represents the area that needs to be evacuated within $4 \mathrm{~min}$ in the case of a December 2002-type tsunami event. It contains 31 holiday rental buildings and two hotels. The yellow zone is the $5 \mathrm{~m}$ high margin of error zone to be considered during an evacuation; and the green zone, above the 15 $\mathrm{m}$ contour line, corresponds to the safety zone. Note that the yellow zone is sometimes absent from the study area due to the presence of the cliff: the red zone 


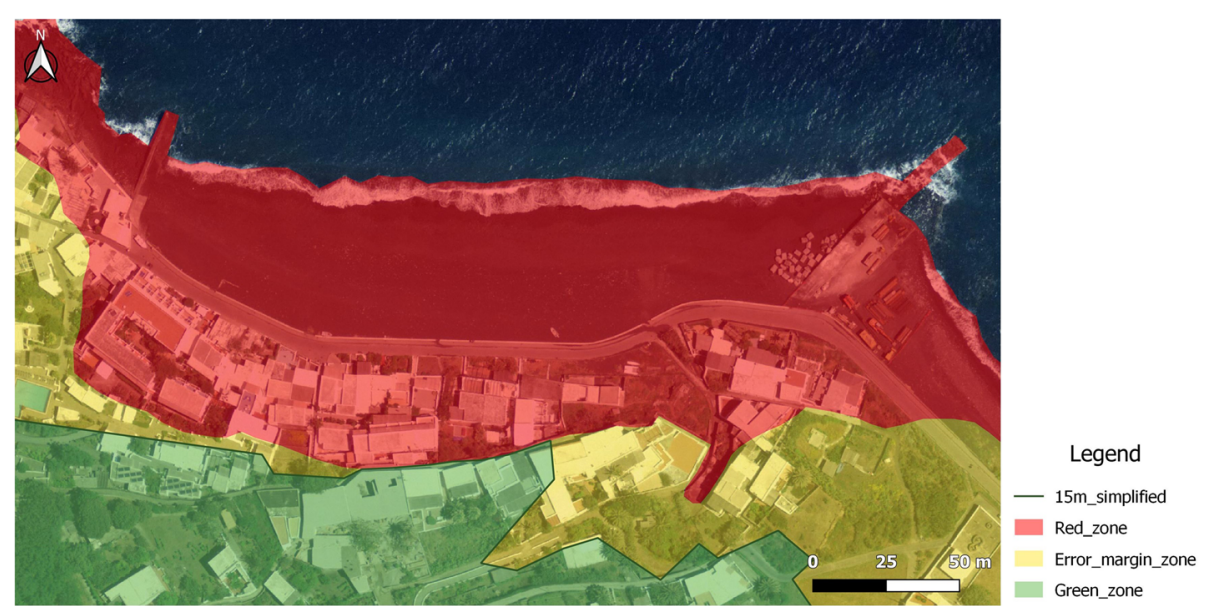

Fig. 6 Hazard areas in Ficogrande

extends to the base of the cliff, and the green zone begins on the top of it.

\section{Evacuation times}

Fig. 7 shows all possible evacuation routes from all possible starting points within the Ficogrande sector. In addition to the building exits, evacuation routes and exits from the beach needed to be defined. On the beach, five exits are present. However, some are not accessible due to either their poor state of repair or erosion of sand due to the 23 December 2019 storm that left the exit points hanging $1 \mathrm{~m}$ above the beach level. As of January 2020, only the two exits at the north end of the beach were, thus, usable. However, paths on the beach were traced to join each of the five exits. The starting points of the tests for each evacuation are depicted by the red centroids within the populated start grid and the arrival points by the entry points (RAEP) to the refuge areas (Fig. 7).

We can now use this network to estimate evacuation time and optimal evacuation route (Fig. 8). Evacuation time calculations only consider the speeds registered for the road network. They do not include time needed to exit the building, and there is no reaction time factor or consideration of congestion phenomena, as these cannot be included using the QNEAT3 plugin. The test results show that the fastest evacuation route involves following Via Marina either west or east to the central stairway (Fig. 8). Consequently, 79 departure points are evacuated to RAEP13, 14 to RAEP14, and just one to RAEP12. This means that more than three-quarters of the people in this sector (potentially 300-375 individuals) will evacuate to the same point using the same narrow staircase that feeds RAEP13 (Fig. 9). The distribution of individuals between the different Refuge Area Entry Points

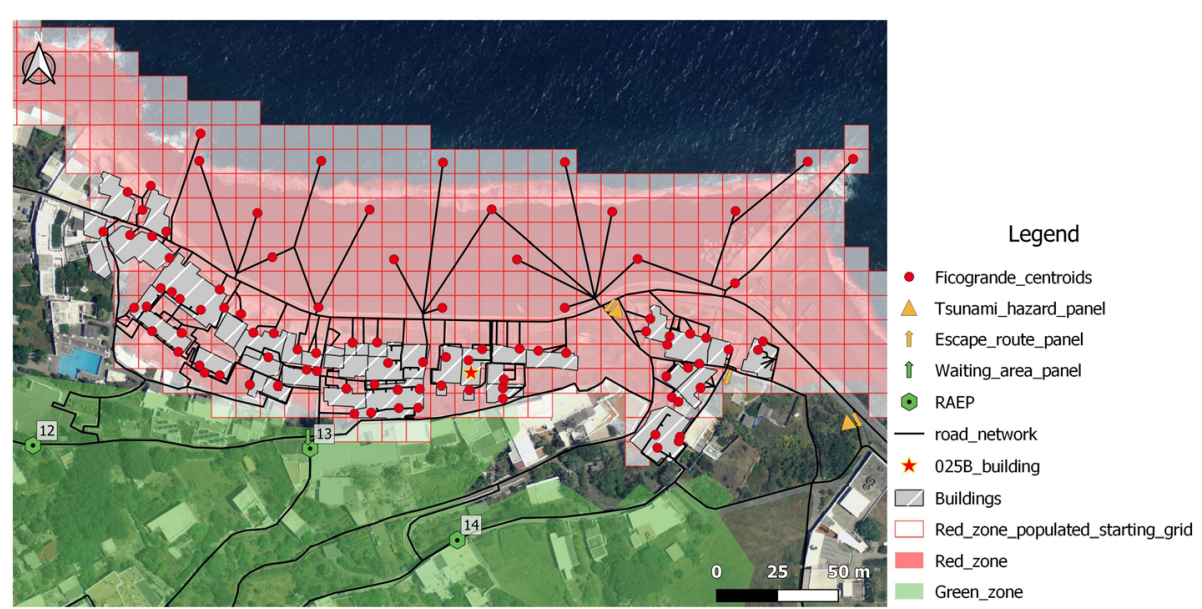

Fig. 7 Evacuation routes from all starting centroids 


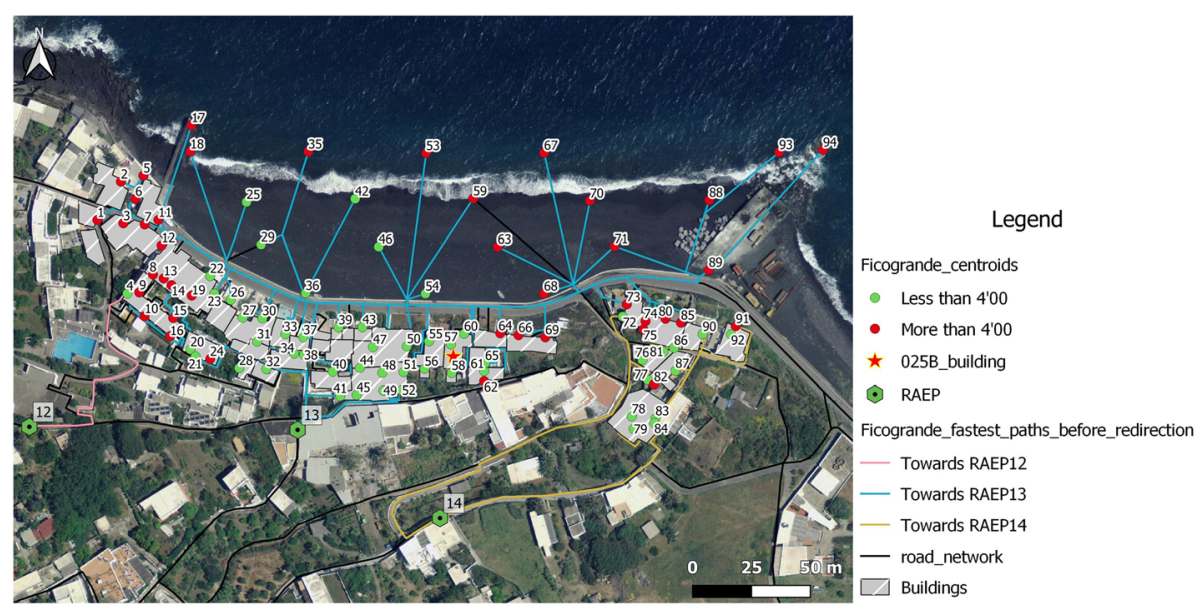

Fig. 8 Evaluation of the possibility of evacuating in less than 4 min in Ficogrande

is therefore not homogenous and will create a much larger group of people at RAEP13 and may thus be flagged as a potential bottle neck (cf. Ma et al. 2014).

Figure 8 shows that the nearest RAEP in terms of distance is not always the one that is reached most quickly, as can be seen with departure points $73,74,80$ and 85 in the northeast corner of the map. These points need to be evacuated in the direction of danger (towards and along the coast) and then up the staircase of Via Nunziante to RAEP13 instead of up the first inland road encountered (to RAEP 14). Evacuation times of the whole Ficogrande sector are highly variable (Table 4), ranging from $47 \mathrm{~s}$ (Point 41) to $7 \mathrm{~min}$ and $6 \mathrm{~s}$ (Point 94).
A landslide-generated tsunami from the foot of the Sciara del Fuoco will arrive in Ficogrande in less than 4 min after the siren alert. We see here that of the 94 departure points, 73 can be evacuated (i.e., 67 points divided between 31 buildings, plus six points on the beach) in less than $4 \mathrm{~min}$ (Table 4 , green points on Fig. 8). This means that 21 points are non-evacuable (i.e., 7 points divided between four buildings, plus 14 points on the beach) in 4 min (red points on Fig. 8). Once set up for Ficogrande, the same type of evacuation maps with evacuable and non-evacuable points could also be produced for all other red zone regions, the GIS allowing ease of map generation and update. The
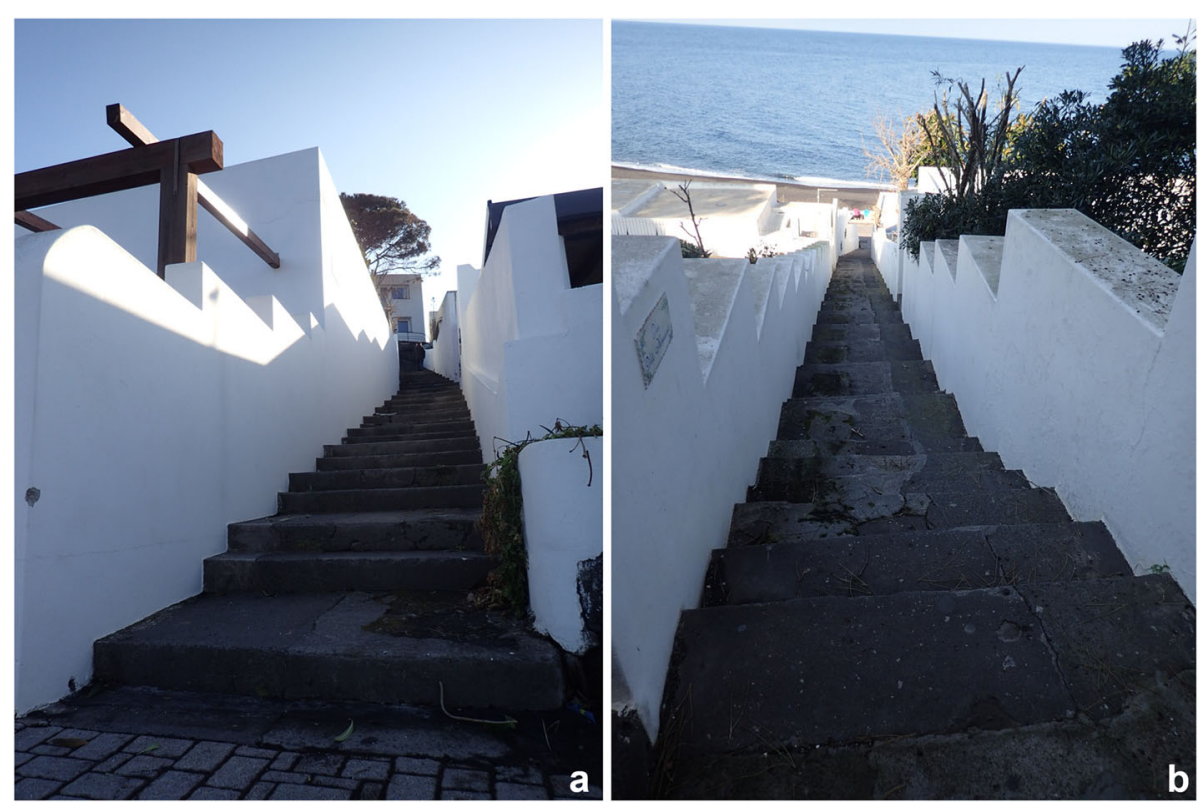

Fig. 9 Main access to Ficogrande: Via Nunziante. a From the beach going up to the RAEP13. b From the RAEP13 down towards the beach 
Table 4 Evacuation times in minutes from each evacuation point on Fig. 8, except for Via Sole which is marked on Fig. 3

\begin{tabular}{|c|c|c|c|c|c|c|c|c|c|c|c|c|c|c|c|c|c|c|c|c|}
\hline \multicolumn{21}{|c|}{ Numerical tests } \\
\hline ID & 1 & 2 & 3 & 4 & 5 & 6 & 7 & 8 & 9 & 10 & 11 & 12 & 13 & 14 & 15 & 16 & 17 & 18 & 19 & 20 \\
\hline Time (min) & $3^{\prime} 32$ & $3 \prime 39$ & $3^{\prime} 17$ & $3 \prime 35$ & 3'38 & $3^{\prime} 22$ & $3^{\prime} 04$ & $3^{\prime} 22$ & 3'15 & $2^{\prime} 55$ & $3^{\prime} 00$ & $3^{\prime} 00$ & $3^{\prime} 18$ & $3^{\prime} 12$ & $2^{\prime} 58$ & $2^{\prime} 35$ & $4^{\prime} 37$ & $4^{\prime} 22$ & $3^{\prime} 37$ & $2^{\prime} 11$ \\
\hline ID & 21 & 22 & 23 & 24 & 25 & 26 & 27 & 28 & 29 & 30 & 31 & 32 & 33 & 34 & 35 & 36 & 37 & 38 & 39 & 40 \\
\hline Time (min) & $2{ }^{\prime} 09$ & $2^{\prime} 40$ & $2^{\prime} 43$ & $1 ' 57$ & $3^{\prime} 31$ & $2^{\prime} 46$ & $2^{\prime} 37$ & $1 ' 38$ & $3 \prime 09$ & $2^{\prime} 26$ & $1^{\prime} 48$ & $1 ' 13$ & $2^{\prime} 24$ & $1 ' 12$ & $4^{\prime} 26$ & $2^{\prime} 03$ & 2'17 & $1 ' 06$ & $2^{\prime} 13$ & $1 ' 20$ \\
\hline ID & 41 & 42 & 43 & 44 & 45 & 46 & 47 & 48 & 49 & 50 & 51 & 52 & 53 & 54 & 55 & 56 & 57 & 58 & 59 & 60 \\
\hline Time (min) & $0^{\prime} 47$ & $3^{\prime} 45$ & $2^{\prime} 21$ & $1 ' 33$ & $2^{\prime} 22$ & $3^{\prime} 25$ & $2^{\prime} 10$ & $1 ' 50$ & $2^{\prime} 06$ & $2^{\prime} 50$ & $2^{\prime} 04$ & $1 ' 57$ & $4^{\prime} 49$ & $2^{\prime} 47$ & $2^{\prime} 58$ & $3^{\prime} 22$ & $3^{\prime} 24$ & $3 \prime 37$ & $4^{\prime} 23$ & $3^{\prime} 08$ \\
\hline ID & 61 & 62 & 63 & 64 & 65 & 66 & 67 & 68 & 69 & 70 & 71 & 72 & 73 & 74 & 75 & 76 & 77 & 78 & 79 & 80 \\
\hline Time (min) & $3^{\prime} 58$ & $4^{\prime} 00$ & $4^{\prime} 56$ & $3 \prime 13$ & $3^{\prime} 42$ & $3^{\prime} 46$ & $5^{\prime} 44$ & $4^{\prime} 05$ & $33^{\prime} 34$ & $4^{\prime} 57$ & $4^{\prime} 29$ & $3^{\prime} 50$ & $3^{\prime} 58$ & $4^{\prime} 26$ & $4^{\prime} 24$ & $3^{\prime} 26$ & $3^{\prime} 56$ & $2^{\prime} 24$ & $1 ' 57$ & $4^{\prime} 22$ \\
\hline ID & 81 & 82 & 83 & 84 & 85 & 86 & 87 & 88 & 89 & 90 & 91 & 92 & 93 & 94 & & & & & & \\
\hline Time (min) & $3^{\prime} 18$ & $4{ }^{\prime} 01$ & $2^{\prime} 01$ & $2^{\prime} 00$ & $4^{\prime} 34$ & $33^{\prime} 03$ & $2^{\prime} 45$ & $5^{\prime} 43$ & $4^{\prime} 28$ & $33^{\prime} 03$ & $4^{\prime} 01$ & $3^{\prime} 567^{\prime} 02$ & 7'06 & & & & & & & \\
\hline \multicolumn{21}{|c|}{ Field tests of January 2020} \\
\hline \multicolumn{7}{|c|}{ Towards RAEP11 (Via Sole) } & \multicolumn{7}{|c|}{ Towards RAEP13 } & \multicolumn{7}{|c|}{ Towards RAEP14 } \\
\hline ID & 11 & 17 & & & & & 11 & 17 & 51 & 52 & 71 & 89 & 94 & 89 & & & & & & \\
\hline Time (min) & $3^{\prime} 17$ & $3^{\prime} 51$ & & & & & $1^{\prime} 48$ & $2^{\prime} 22$ & $1 ' 30$ & $0{ }^{\prime} 56$ & $2 ' 55$ & $4^{\prime} 00$ & 4'59 & $2^{\prime} 30$ & & & & & & \\
\hline
\end{tabular}

In bold are the times longer than $4 \mathrm{~min}$

resulting evacuation maps for of Piscità, Punta Lena and Scari are given in Appendices C, D and E, respectively.

\section{Individual building evacuation plans}

During the fieldwork, all buildings in the red zone were surveyed, which involved a total of 35 buildings in the Ficogrande sector. A completed example of a building survey is available in Appendix A, this being for building 025B (Fig. 3). We see that building 025B has two large double doors on the ground floor that open directly onto the sea front road that can be accessed by passage over a low wall, making it possible to quickly evacuate the inhabitants of the ground floor (Appendix B). However, evacuation from the first floor involves use of a single door, a gate and descent of a flight of about 20 steps to access the evacuation road (Appendix B). Evacuate from the back of the building is not possible due to the presence of the cliff behind the building, and taking refuge on the roof will not be a solution as the roof level remains below $10 \mathrm{~m}$ and thus might be inundated by the tsunami. However, in cases where the roof height attains the $10 \mathrm{~m}$ level (corresponding to the first or second floor roof depending on the location), roof form could be used as a last resort option for a vertical evacuation shelter. We thus generated maps identifying such possible shelter options (Fig. 10).

We used these detailed building surveys and plans to tailor individual evacuation plans for every room of every building in the red zone, where an example is given in Fig. 11. In designing these maps, we follow standard role, design and symbol usage for fire evacuation maps as posted to room doors in hotels (cf. Kobes et al. 2010; Wang et al. 2014). The aim is to make the maps not seem shocking, but instead to deal with an event that may happen and for which we need to be prepared, as is the same for aircraft or passenger boat style evacuation plans. The example of Fig. 11 is relatively simple, but more complex plans can be produced for larger buildings (containing multiple apartments) and hotels, as in the example of Fig. 12. In such cases, the numerous rooms, corridors, staircases and exits mean that each room/door needs an individual plan with a single line leading to the nearest evacuation exit. Again, such a plan format is familiar to any hotel guest and are intended to be acceptable for use by hotels who wish to protect their clients while not inducing unnecessary fear or driving away clients. All the same, individual plans were delivered in a powerpoint format that could be modified if required.

\section{Discussion}

\section{Area boundary issues}

The position of the red, yellow, and green layer boundaries was set following established guidelines for the hazard zone limits, as defined following the tsunami events that have occurred at Stromboli since December 2002. In some cases, we adjusted the limit of the red zone, moving it inland, if an eye-witness told us of flooding beyond the limit of our initially defined boundary. However, depending on the case in hand, these boundaries are likely to vary significantly (Leone et al. 2012; Péroche 2016). For Stromboli, a landslide of volume greater than that of 30 December 2002, which was $17-20 \times 10^{6} \mathrm{~m}^{3}$ 


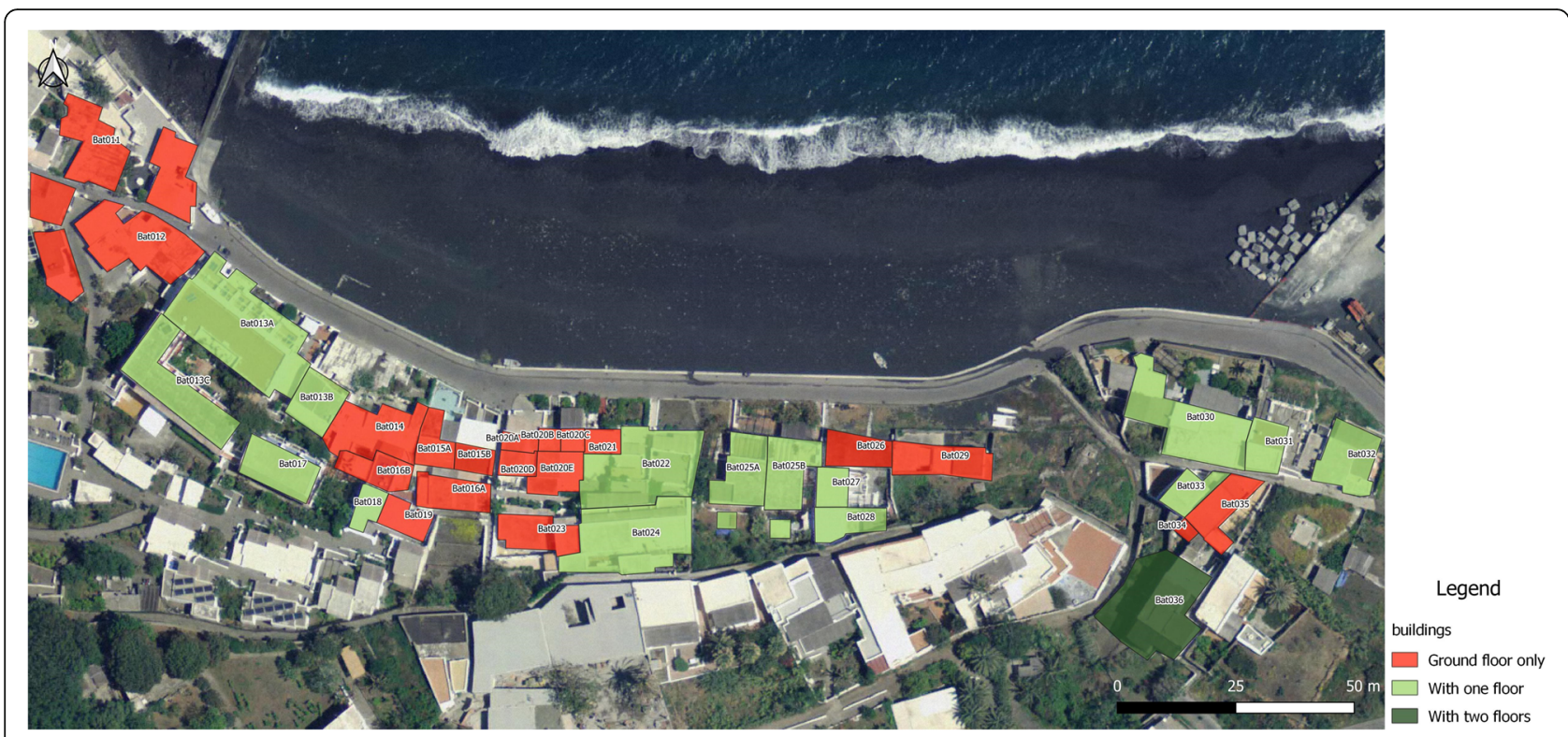

Fig. 10 Consideration of vertical evacuation

for the first tsunami (Chiocci et al. 2003) and produced a wave with an amplitude of $10.9 \mathrm{~m}$ (Tinti et al. 2006a), could produce a larger wave. In our case, the priority area for evacuation was estimated using the 2002 scenario based on literature sources. The 2002 tsunami was the largest recorded tsunami of the last century and has been particularly well-studied in terms of its generation, dynamics, and characteristics (Chiocci et al. 2008).
However, addition of the yellow zone allows for the consideration of a potentially larger event.

\section{Resident interviews}

Five useful points came out of our resident interviews. First, due to the tourist based economy, sites once wellknown for being at-risk from tsunami, and thus not used for residence, are now used as residences, holiday rental

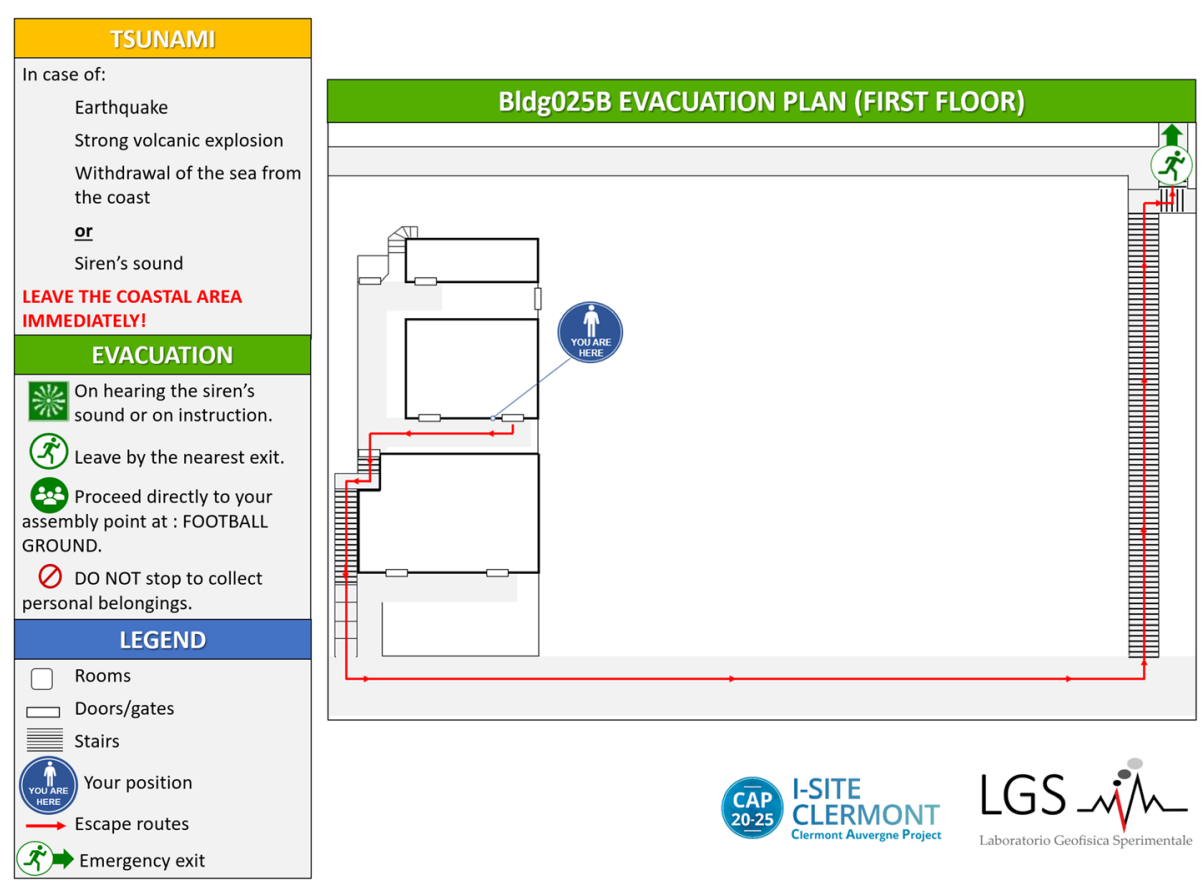

Fig. 11 Personalised evacuation plan for building 025B 


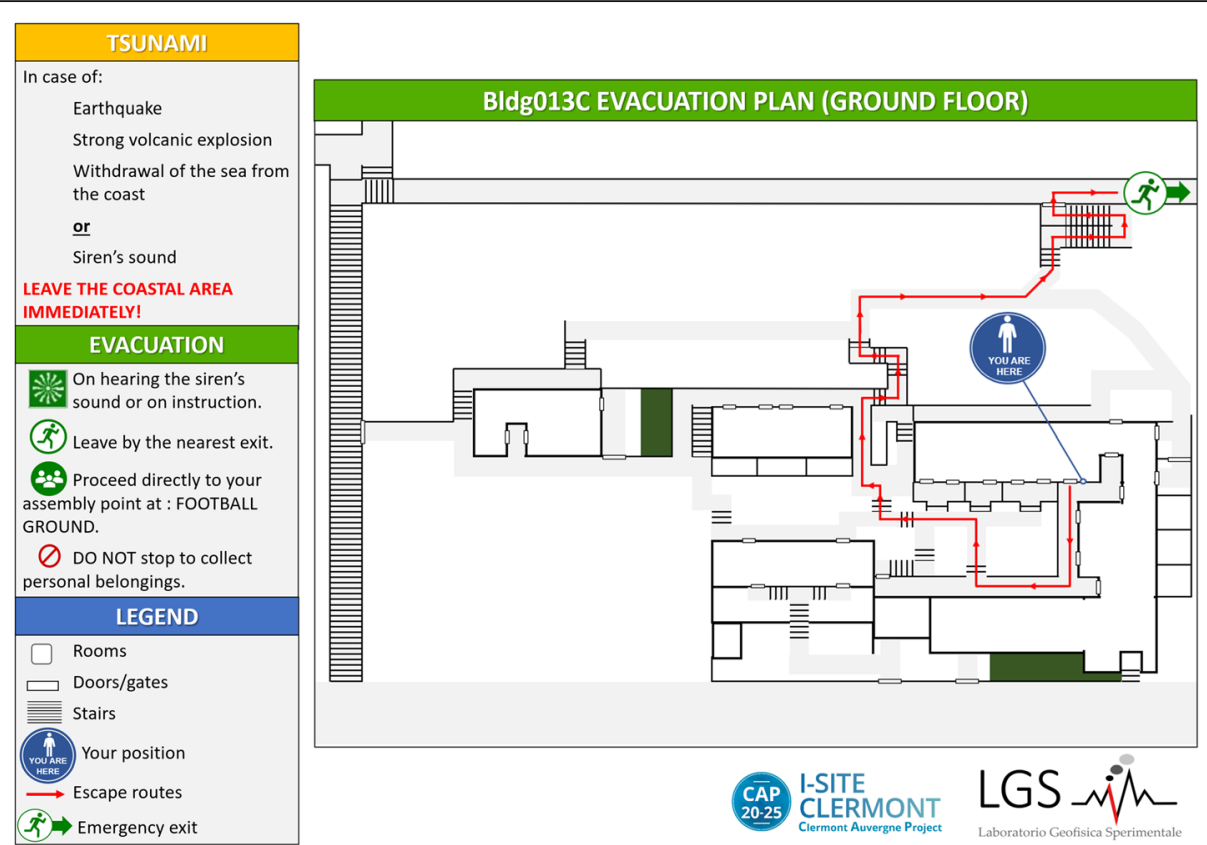

Fig. 12 Personalised evacuation plan for building $013 \mathrm{C}$

and tourist facilities. Indeed, prior to the 1970's coastal areas were just used for warehouses, and fisherman commuted to the coastal zone (known to be a high risk area for tsunami) from their residences higher in the village. Second, there are six buildings occupied all year round at Punta Lena (Fig. 3), making this a very-highrisk zone. Residents are aware that they are in a highrisk zone and know the need to move inland in the event of a tsunami. However, some are fatalistic in that they know they only have $4 \mathrm{~min}$ and know that this is not enough time to save themselves. One resident did, though, say they would climb onto the roof instead, highlighting the need for, and value of, vertical evacuation (cf. Figure 10). Third, some residents were aware that (i) they are too far from the siren to hear it well, and (ii) if they are asleep at the time of the alert may not hear it at-all, highlighting the need to a personalized (app-based) alert. As a result, each evacuation route (i.e., evacuation routes from every point to every evacuation exit) were prepared as individual KMZ files for use in Google Earth or customized apps that trigger distribution of the best evacuation route based on phone location (e.g., Appendix F). Fourth, residents are not necessarily able to move their place of residence out of the red zone, even if they want to, as they are committed to staying in the house where they are due to financial or personal reasons, so that relocation of particularly exposed buildings is not an option. Fifth, interviewees were often told by their parents of the sound that the tsunami made, which was a major memory. This was a rumbling sound due to the entrainment of boulders and was a sound at which locals would immediately self-evacuate, and their descendants (through verbal history) knew to do the same. This last point is emphasized in the local memories collated by Famularo (2013) who states that fishermen in the past knew that, if there was a paroxysm, they should head off shore as quickly as possible to avoid the resulting tsunami. Our maps then provide a guide as to the optimal route to follow and shelter point to seek.

\section{Projectiles and population densities}

The main variable that we could not assess was the presence of unanchored seasonal street furniture such as stalls, beach umbrellas, deck chairs/sunbeds, advertising panels/wooden signs, surf boards, canoes, plastic/ wooden beach walkways, and bar tables/chairs. There will also be an increased incidence of the number of bicycles, Ape, and Vespa in the summer. In the event of a tsunami, these objects will all be picked up, or rolled along, to act as projectiles to cause further structural damage and severe-to-fatal physical injury (Watcharong et al. 2005). The presence, quantity, and distribution of such items, added to the boulders and beach pebbles, will enhance the risk posed by a summer tsunami in a touristic area.

It is also difficult to estimate the population density conditions for an evacuation in the summer period. For some buildings, a reliable estimate of the number of residents in the summer can be made by looking up bedroom capacities available at on-line booking sites. In the winter, we were able to identify inhabited properties in the red zone and interview all residents (with two 
exceptions). Generally, the interviewees also gave information on the summer-use of any neighbouring properties and the number of summer inhabitants, even the period of occupation. However, this information was rare, and, for the summer scenario, a population estimate based on floor space is the only possible solution. Regarding the estimation for the number of beach users, in winter the beaches, generally, are completely empty. The exception are afternoon fishermen (between one and three) who fish off of the Molo (Jetty) at the Eastend of the Ficogrande beach (Fig. 8), residents taking exercise (one or two, either walking or on bicycles), workmen carrying out winter maintenance (one or two) and traffic using the Via Marina (Fig. 3). The total population at any one time was never greater than five, and there were no inhabited buildings in this sector. The total for the summer was estimated by counting the number of beach users on 85 photos found on the internet, considering several summers between 2012 and 2019. We obtained 80-100 people at Ficogrande, 20-25 at Scalo dei Balordi, 40-50 at Spiaggia Lunga, and 250300 at Scari (see Fig. 3 for beach locations).

\section{Evacuation time results: caveats and considerations}

The results of the evacuation modelling tested on the Ficogrande sector show that most of the departure points are evacuated to RAEP13 located above a flight of steps the links the beach road to this point (cf Fig. 9), and that most points can be evacuated within $4 \mathrm{~min}$. However, these times do not consider the possible congestion. The QNEAT3 plugin does not also consider the behaviour of individuals such as reaction time, social interactions, and retrieving belongings (Kelman et al. 2008), nor the slower speed of swimmers leaving the sea or the slower progress of evacuees on the beach due to sand, rocks and lack of footwear. Neither does it take into account the education state of the crowd, the size and design of doors, bottle necks and other problems, such as blockage by slower moving individuals (Ma et al. 2014). Our model must thus be viewed as fastest possible evacuation times, under optimum traffic and reaction conditions. To obtain times that are more representative of a congested scenario, multi-agent simulation micro-scale models (MAS) such as SimWalk could be used (Sahal 2011; Morin 2012; Sahal et al. 2013; Péroche 2016). These models take into account the physical and behavioural characteristics of individuals (Sahal et al. 2013; Péroche 2016). However, such models are complex, computationally heavy and suited for well-constrained, scenarios of limited size, such as evacuation from individual buildings, cruise ships or shopping centres, or even through single doors or tunnels (Lämmel et al. 2010; Wang et al. 2014). Our objective is to produce a map of "best option" (quickest) evacuation routes, and to identify locations in need of the most time for evacuation, for all points across an entire village sector. In our case the village sector to be evacuated is $2.7 \mathrm{~km}$ long and with an area of $0.18 \mathrm{~km}^{2}$, contains 123 individual buildings and 534 doors, and potentially hosts thousands of people. Any one of these building-door-agent combinations could be the focus of a micro-model-based study and is thus not our objective.

However, our large-scale modelling can allow identification of potential improvements to the evacuation network and to make recommendations on the placement of signage and vertical evacuation structures. In the case of RAEP13, for example, it points to the possible need to relieve the load on the Via Nunziante stairs and, thus, RAEP13 by redirecting to RAEP12. The redesigned plan is given in Fig. 13. Our methodology allows us to produce three levels of evacuation map. The first level is zonal, and shows all evacuations from all points to all RAEP in any given village zone (Fig. 13a). The second level is for individual RAEP and focuses on all evacuation routes ending at any given RAEP where, to aid in clarity, on the doors linked to that RAEP are mapped (Fig. 13b). The third level is for each individual door with, again, no other door marked so as to maximise clarity (Fig. 13c). In Appendix G we also show an example for a beach exit evacuation point. In total we produced four level 1 maps, 23 level 2 maps and 316 level 3 maps, where all level 1 maps are given in Appendices $\mathrm{C}$, D, E and Fig. 8.

Exit signs in hotels/buildings, as well as DPC signage, should then be set up to direct the evacuation flow accordingly (Bertolaso et al. 2009). This may involve a rethink of signage, as the only exit signs inside hotels are for the case of fire and tend to direct guests to the reception desk which in the case considered here is located on the sea front. Adding specific exit signs and evacuation plans directing guests out of the hotel and to the nearest RAEP (Fig. 7) would facilitate and ensure better evacuation in the case of a tsunami. This addresses the idea that for short fuse events (such as that considered here), there is little time for people to educate themselves. People unfamiliar with the area will look to follow the behaviour of others. Consequently, and in areas with visitor populations, it is useful to develop educational and training programs for the visitor industry (e.g., Johnston et al. 2007; Johnston et al. 2016; Blake et al. 2018).

No matter which solution is chosen, it is impossible to evacuate all of the Ficogrande sector completely in the time allotted (i.e., $4 \mathrm{~min}$ ). At least $7 \mathrm{~min}$ and $6 \mathrm{~s}$ are necessary to evacuate this area in the absence of congestion and bottle necking. This value does not take into account the reaction time to the siren which could vary 

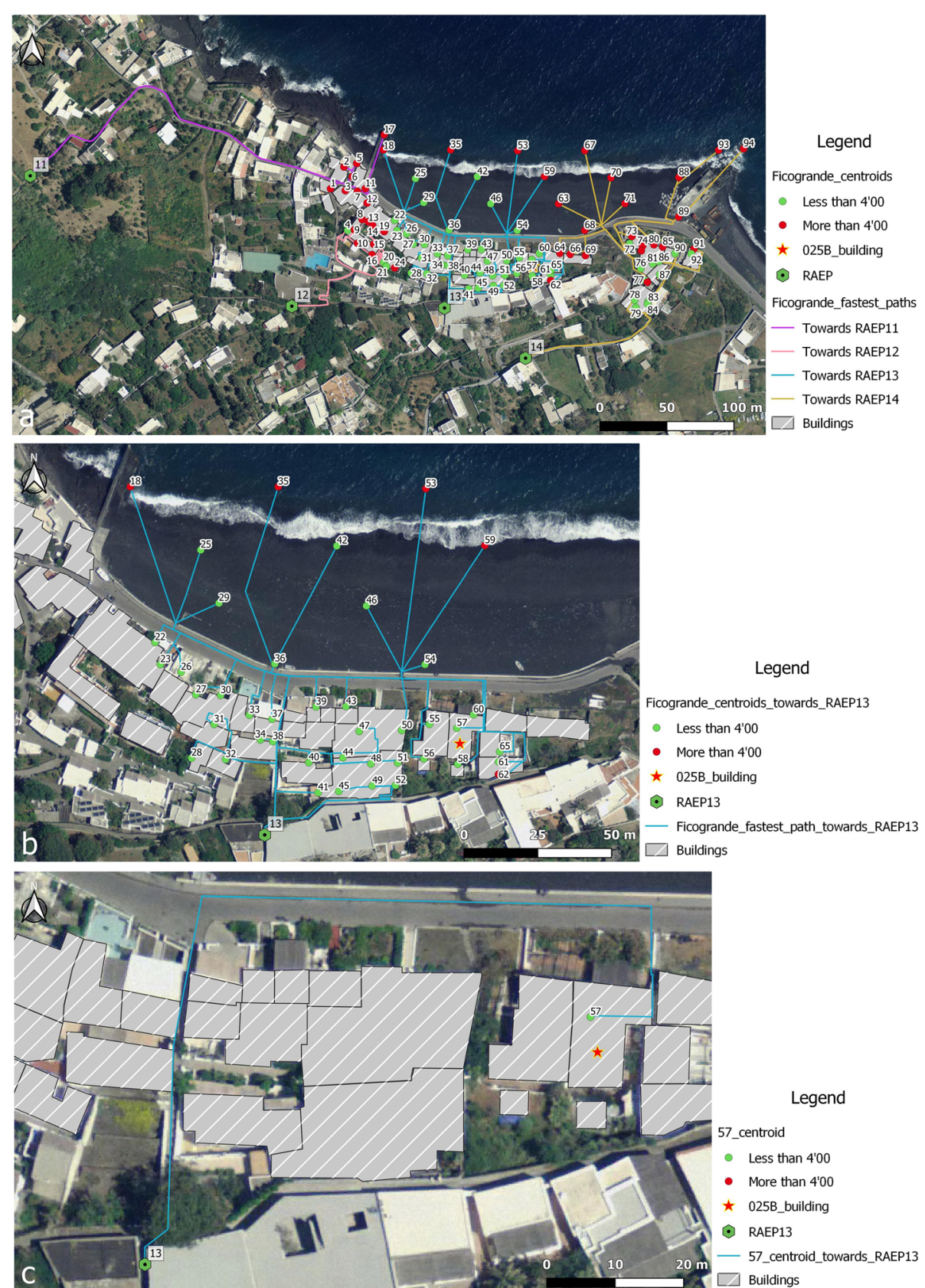

Fig. 13 Modification of evacuation routes to improve traffic flow for Ficogrande. a Evacuation of all the centroids in the Ficogrande zone. $\mathbf{b}$ Specific evacuation of the centroids to the RAEP13. $\mathbf{c}$ Individual evacuation of 57 centroid to the RAEP13

between no time for highly aware individuals to several minutes for individuals with no awareness or in a situation which means reaction is compromised (e.g., people sleeping, parents with children, individuals with disabilities). For these cases, we arbitrarily add 3 min to the evacuation time, so that the minimum warning time needed to evacuate the entire zone is $10 \mathrm{~min}$ (Appendix $\mathrm{H}$ ). The 10-min of extra time would also allow us to optimise the evacuation plan to better distribute pedestrian capacity across the three evacuation exits (RAEP) from this sector. Thus, we point to the value of such mapping in guiding tolerable thresholds for warning times. In the case where only a four-minute warning is possible, vertical evacuation towers with sufficient capacity needs to be an option (Park et al. 2012; Ashar et al. 2014), where our methodology can also point to suitable roof-top options. Our building surveys, for example, showed that all roofs were flat, 
strong, and suitable for vertical evacuation, and allowed us to define those which had two storeys and an adequate roof to serve as a vertical evacuation point in case of last resort (Fig. 10). However, this needs to be considered only as a last resort option due to the chance of building failure (Nakano 2010) and the possibility of the tsunami overtopping the building height.

Our evacuation time tests of Table 4 are generally twice as fast as those obtained by the model. For example, modelled evacuation time from point 11 (Fig. 8) is $3 \mathrm{~min}$, whereas we achieved an evacuation in $1 \mathrm{~min}$ and $48 \mathrm{~s}$. Thus, individual evacuations could be quicker. This, however, is because we ran and not all individuals may have the same capacity. We note though, that the survey of Gregg et al. (2006) of survivors of the 2004 Sumatra tsunami found that most respondents did indeed run "as fast as they could" but could not identify a safe place. This was also a problem with our tests. The first tests from points 11 and 17 (Fig. 8) were unguided. The quickest evacuation route up Via Nunziante was not obvious, so evacuees ran up Via Regina Elena to evacuate the beach to the west, eventually finding the Via Sole RAEP (RAEP 11, Fig. 13a) after between 3 and 4 min (Table 4), in spite of running as fast as they could. This further points to the value of carefully calibrated evacuation plans.

\section{Conclusion}

We here develop, test, and apply a method to assess the quickest evacuation routes from high-risk, populated, coastal zones exposed to tsunami ingress. The method allows the time, and route, of evacuation from every door or beach access gate in an exposed zone to the nearest (by time) exit point from the high-risk area. Key layers to the GIS, after definition of the exposed area (the red zone) and the safe area (the green zone) which are based on land inundated during historic tsunamis, is door location (in all mapped buildings) and quality of the road/path network. This can only be assessed by field mapping, during which the population can also be interviewed so that their level of awareness regarding the hazard can be assessed. This field observation approach also has the advantage of identifying those most exposed to the hazard, i.e., those living permanently in, or regular visitors to, the red zone and their needs (in terms of evacuation plans).

For the Stromboli case tested here, we find that building design is amenable to quick evacuation, where of the 123 buildings identified in the red zone there were 534 doors, for an average of around 4 doors per building. In addition, roofs were flat, strong, and easy to access making them a last resort vertical evacuation option in case of the need of immediate evacuation. For horizontal evacuation, we focused on the popular beach of
Ficogrande behind which there are two hotels with a total summer night capacity of 141 . For this area, 31 of the 35 buildings could be evacuated within the 4-min threshold. For complete evacuation, our simulations show that a minimum of $10 \mathrm{~min}$ of warning is required. Such a warning time would also allow a more evenly distributed use of evacuation routes so that any single route does not suffer from congestion or bottle necking effects. If such a warning time is not possible, our maps also allow the location and capacity of vertical evacuation shelters to be assessed, and best routes to them to be defined.

The tragic loss among residents and tourists during the tsunamis generated by the 26 December 2004 Aceh earthquake grimly demonstrated the potential for disaster when waves inundate coastlines where sea-front tourist facilities are well-developed (Kelman et al. 2008). Our methodology being applicable to a large spatial scale involving thousands of agents, could be used for any population exposed to tsunami. This applies especially to communities within minutes of the potential tsunami source, as is the case on small volcano islands such as Stromboli, and the other Aeolian Islands with coastal tourist development. Output maps can be used directly as individual evacuation plans tailored to each exposed point, but can also be used to guide signage placement and other mitigation efforts, as well as set up of minimum warning times and alerting thresholds and protocols.

\section{Supplementary Information}

The online version contains supplementary material available at https://doi. org/10.1186/s13617-021-00104-9.

Additional file 1: Appendix A. Typical example of a completed building survey (Bldg025B).

Additional file 2: Appendix B. Arrangement of building 025B. (a) The overall view of the building. (b) The two double doors on the ground floor. (c) The staircase to the first floor. (d) The single door on the first floor. (e) The two single doors on the first floor. (f) The single door at the back of the building.

Additional file 3: Appendix C. Piscità evacuation map for a 4-min warning scenario.

Additional file 4: Appendix D. Punta Lena evacuation map for a 4-min warning scenario.

Additional file 5: Appendix E. Scari evacuation map for a 4-min warning scenario.

Additional file 6: Appendix F. Example of $\mathrm{KMZ}$ file for point 57 (Bldg025B) with (a) its summary table and (b) its layout on Google Earth.

Additional file 7: Appendix G. Evaluation of the possibility of evacuating in less than 4 min in Piscità (a) Evacuation of all the centroids in the Piscità zone. (b) Specific evacuation of the centroids to the RAEP1. (c) Individual evacuation of 101 centroid to the RAEP1.

Additional file 8: Appendix H. Ficogrande evacuation map for a 10min warning scenario.

\section{Acknowledgements}

We would like to warmly thank the inhabitants of Stromboli for their help, including Massimiliano of the Ingrid bar for opening out of season. We thank 
Paolo Russo for his insights on the main coastal vulnerabilities and for his detailed testimony on the local tsunamis. We would also like to thank Mathieu Péroche and Yoann Médard for our scientific discussions about the modelling software. We are grateful to two anonymous reviewers for their supportive comments, and to the handling of Carina Fearnley.

\section{Authors' contributions}

This project was co-conceived by Emmie M. Bonilauri, Andrew J.L. Harris, Julie Morin, Maurizio Ripepe, Domenico Mangione and Stefano Ciolli. Domenico Mangione and Stefano Ciolli provided the basic layers of the GIS and open questions regarding evacuation during a tsunami, while Maurizio Ripepe and Giorgio Lacanna provided hazard information and access to the tsunami warning system managed by the Laboratorio di Geofisica Sperimentale (Università degli Studi di Firenze). Maurizio Ripepe also organised the logistics to enable the field surveys to be completed during the fieldwork. Emmie M. Bonilauri, Andrew J.L. Harris, and Julie Morin have collected the field data on evacuation times and itineraries, with the occasional but indispensable help of Maria Cusolito and Pauline Deguy, and integrated all the data into the GIS. All the co-authors have agreed with the current version of the paper.

\section{Funding}

This research was financed by the French government IDEX-ISITE initiative16IDEX-0001 (CAP 20-25). This work is a contribution to the EUROVOLC project, under the EU Horizon 2020 Research and Innovation Action, grant No. 731070. This is ClerVolc Publication No. 475.

\section{Availability of data and materials}

All maps produced as part of work of Emmie M. Bonilauri are available on request, but the GIS is property of DPC and is thus only available for situations involving officially sanctioned access and collaboration.

\section{Declarations}

\section{Competing interests}

The authors declare that they have no competing interests.

\section{Author details}

${ }^{1}$ Université Clermont Auvergne, CNRS, IRD, OPGC, Laboratoire Magmas et Volcans, Clermont - Ferrand, France. ${ }^{2}$ Department of Geography, University of Cambridge, Cambridge, UK. ${ }^{3}$ Laboratorio di Geofisica Sperimentale, Università degli Studi di Firenze, Florence, Italy. ${ }^{4}$ Dipartimento della Protezione Civile, Rome, Italy. ${ }^{5}$ Lipari town council, Lipari, Aeolian Islands, Italy. ${ }^{6}$ Dipartimento di Scienze della Terra, Università degli Studi di Firenze, Florence, Italy.

\section{Received: 27 November 2020 Accepted: 24 March 2021}

\section{Published online: 04 June 2021}

\section{References}

Ashar F, Amaratunga D, Haigh R (2014) The analysis of tsunami vertical shelter in Padang city. Proc Econ Finance 18:916-923 https://doi.org/10.1016/s22125671(14)01018-1

Barberi F, Rosi M, Sodi A (1993) Volcanic hazard assessment at Stromboli based on review of historical data. Acta Vulcanol 3:173-187

Bertolaso G, De Bernardinis B, Bosi V et al (2009) Civil protection preparedness and response to the 2007 eruptive crisis of Stromboli volcano, Italy. J Volcanol Geotherm Res 182(3-4):269-277. https://doi.org/10.1016/j. jvolgeores.2009.01.022

Blake D, Johnston D, Leonard G, McLaren L, Becker J (2018) A citizen science initiative to understand community response to the Kaikoura earthquake and tsunami warning in Petone and Eastbourne, Wellington, Aotearoa/New Zealand. Bull Seismol Soc Am 108: https:/doi.org/10.1785/0120170292(3B):1807-1817

Bonaccorso A, Calvari S, Garfi G et al (2003) Dynamics of the December 2002 flank failure and tsunami at Stromboli volcano inferred by volcanological and geophysical observations. Geophys Res Lett 30 https://doi.org/10.1029/2003 GL017702

Calvari S, Branca S, Corsaro RA, de Beni E, Miraglia L, Norini G, Wijbrans J, Boschi E (2011) Reconstruction of the eruptive activity on the NE sector of Stromboli volcano: timing of flank eruptions since $15 \mathrm{ka}$. Bull Volcanol 73(1):101-112. https://doi.org/10.1007/s00445-010-0412-5
Calvari S, Spampinato L, Lodato L et al (2005) Chronology and complex volcanic processes during the 2002-2003 flank eruption at Stromboli volcano (Italy) reconstructed from direct observations and surveys with a handheld thermal camera: THERMAL SURVEYS AND STROMBOLI ERUPTION. J Geophys Res 110 https://doi.org/10.1029/2004JB003129

Chiocci F, Bosman A, Romagnoli C et al (2003) The December 2002 Sciara del Fuoco (Stromboli Island) submarine landslide: a first characterization, p 12069

Chiocci F, Romagnoli C, Tommasi P (2008) The Stromboli 2002 tsunamigenic submarine slide: characteristics and possible failure mechanisms. J Geophys Res 113: https://doi.org/10.1029/2007JB005172(B10)

Corazzato C, Francalanci L, Menna M, Petrone CM, Renzulli A, Tibaldi A, Vezzoli L (2008) What controls sheet intrusion in volcanoes? Structure and petrology of the Stromboli sheet complex, Italy. J Volcanol Geotherm Res 173(1-2):2654. https://doi.org/10.1016/j.jvolgeores.2008.01.006

Daamen W, Hoogendoorn S (2010) Capacity of doors during evacuation conditions. Proc Eng 3:53-66 https://doi.org/10.1016/j.proeng.2010.07.007

Dall'Osso F, Dominey-Howes D (2010) Public assessment of the usefulness of "draft" tsunami evacuation maps from Sydney, Australia - implications for the establishment of formal evacuation plans. Nat Hazards Earth Syst Sci 10. https://doi.org/10.5194/nhess-10-1739-2010(8):1739-1750

EPSG database (2019) Coordinate systems worldwide. http://epsg.io. Accessed 26 May 2020.

Famularo F (2013) Stromboli, stelle di fuoco. I racconti delle eruzioni. Strombolibri 136

Favalli M, Boschi E, Mazzarini F, Pareschi M (2009) Seismic and landslide source of the 1908 straits of Messina tsunami (Sicily, Italy). Geophys Res Lett 36(16): 16304. https://doi.org/10.1029/2009GL039135

FEMA (2019) Guidelines for design of structures for vertical evacuation from tsunamis | FEMA.gov. https://www.fema.gov/media-library/assets/ documents/14708. Accessed 29 May 2020

Forcael E, González V, Orozco F et al (2014) Ant Colony optimization model for tsunamis evacuation routes. Comput Aided Civ Infrastructure Eng 29(10):723737. https://doi.org/10.1111/mice.12113

Fraser S, Wood N, Johnston D et al (2014) Variable population exposure and distributed travel speeds in least-cost tsunami evacuation modelling. Nat Hazards Earth Syst Sci 14(11):2975-2991. https://doi.org/10.5194/nhess-14-2 975-2014

Giachetti T, Paris R, Kelfoun K, Ontowirjo B (2012) Tsunami hazard related to a flank collapse of Anak Krakatau volcano, Sunda Strait, Indonesia. Geol Soc Lond Spec Publ 361(1):79-90. https://doi.org/10.1144/SP361.7

Global Volcanism Program (2019) Report on Stromboli (Italy). Bull Glob Volcanism Netw 44(9):3. https://doi.org/10.5479/si.GVP.BGVN201909-211040

Gregg C, Houghton B, Paton D et al (2006) Natural warning signs of tsunamis: human sensory experience and response to the 2004 great Sumatra earthquake and tsunami in Thailand. Earthquake Spectra 22(3_suppl):671691. https://doi.org/10.1193/1.2206791

Hamacher HW, Tjandra SA (2001) Mathematical modelling of evacuation problems: a state of art, $\mathrm{p} 45$

Hornig-Kjarsgaard I, Keller J, Koberski U et al (1993) Geology, stratigraphy and volcanological evolution of the island of Stromboli, Aeolian arc, Italy. Acta Vulcanol 3:21-68

International Tsunami Information Center (2021). http://itic.ioc-unesco.org/index. php. Accessed 25 Feb 2021

Jo A, Sano T, Ikehata Y, Ohmiya Y (2014) Analysis of crowd flow capacity through a door connected to a crowded corridor. Transportation Res Proc 2:10-18 https://doi.org/10.1016/j.trpro.2014.09.003

Johnston D, Becker J, Gregg C, Houghton B, Paton D, Leonard G, Garside R (2007) Developing warning and disaster response capacity in the tourism sector in coastal Washington, USA. Disaster Prev Manag Int J 16(2):210-216. https://doi.org/10.1108/09653560710739531

Johnston D, Tarrant R, Tipler K et al (2016) Towards tsunami-safer schools in the Wellington region, New Zealand: evaluating drills and awareness programmes. Aust J Emerg Manag 31:59-66

Kelman I, Spence R, Palmer J, Petal M, Saito K (2008) Tourists and disasters: lessons from the 26 December 2004 tsunamis. J Coast Conserv 12(3):105113. https://doi.org/10.1007/s11852-008-0029-4

Kobes M, Helsloot I, De Vries B et al (2010) Way finding during fire evacuation; an analysis of unannounced fire drills in a hotel at night. Build Environ 45(3): 537-548. https://doi.org/10.1016/j.buildenv.2009.07.004

Kokelaar P, Romagnoli C (1995) Sector collapse, sedimentation and clast population evolution at an active island-arc volcano: Stromboli, Italy. Bull Volcanol 57(4):240-262. https://doi.org/10.1007/BF00265424 
Lacanna G, Ripepe M (2020) Genesis of tsunami waves generated by Pyroclastic flows and the Early-Warning system. Abstract volume, $4^{\text {th }}$ Conference A. Rittmann, February 2020, Catania, Italy

Lacanna G, Ripepe M. Tsunami wave by Pyroclastic flows recorded in near field, in preparation

Lämmel G, Rieser M, Nagel K et al (2010) Emergency preparedness in the case of a tsunami-evacuation analysis and traffic optimization for the Indonesian City of Padang, pp 1-12

Leone F, Péroche M, Gutton R (2012) Contribution méthodologique pour l'aide à la planification des évacuations de population en cas de tsunami. Modélisation spatiale et temporelle de l'accessibilité des zones refuges (Martinique, France). Projet Interreg CARIBSAT, IRD Martinique et UMR GRED, p 111

Leone F, Péroche M, Gutton R (2014) Le risque tsunami en Martinique : planifier une évacuation préventive en optimisant l'accessibilité de sites refuges. VertigO 14(Numéro 2):13. https://doi.org/10.4000/vertigo.15046

Leone F, Péroche M, Lagahé E, Gherardi M, Sahal A, Vinet F, Hachim S, Lavigne F (2013) Modélisation de l'accessibilité territoriale pour l'aide à la gestion de crise tsunami (Mayotte, France). Ann Géographie 693(5):502-524. https://doi. org/10.3917/ag.693.0502

Leone F, Péroche M, Robustelli M et al (2018) Planifier les évacuations en cas de tsunami : la méthode EXPLOIT. Guide méthodologique. UMR GRED, Université Paul-Valéry 3 et IRD, p 73

Løvholt F, Fraser S, Salgado-Gálvez M, et al (2019) Global trends in advancing tsunami science for improved hazard and risk understanding. Contributing paper to GAR 2019

Ma J, Xu SM, Li T, Mu HL, Wen C, Song WG, Lo SM (2014) Method of bottleneck identification and evaluation during crowd evacuation process. Proc Eng 71: 454-461 https://doi.org/10.1016/j.proeng.2014.04.065

Maramai A, Graziani L, Alessio G, Burrato P, Colini L, Cucci L, Nappi R, Nardi A, Vilardo G (2005b) Near- and far-field survey report of the 30 December 2002 Stromboli (southern Italy) tsunami. Mar Geol 215(1-2):93-106. https://doi. org/10.1016/j.margeo.2004.11.009

Maramai A, Graziani L, Tinti S (2005a) Tsunamis in the Aeolian Islands (southern Italy): a review. Mar Geol 215(1-2):11-21. https://doi.org/10.1016/j.margeo.2 004.03.018

Médard Y, Foulquier P: Tutoriel de l'extension QNEAT3 sous QGIS, in preparation

Morin J (2012) Gestion institutionnelle et réponses des populations face aux crises volcaniques : études de cas à La Réunion et en Grande Comore. Thèse de doctorat, Université de La Réunion, Saint-Denis, La Réunion. 368 p. (+ annexes 88p.), https://halshs.archives-ouvertes.fr/tel-00863366/. Accessed 30 Sept 2020

Morin J, Coster B, Paris R et al (2008) Tsunami-resilient communities' development in Indonesia through educative actions: lessons from the 26 December 2004 tsunami. Disaster Prev Manag 17(3):430-446. https://doi. org/10.1108/09653560810887338

Nakano Y (2010) Design load evaluation for tsunami shelters based on damage observations after Indian ocean Tsunami disaster due to the 2004 Sumatra Earthquake. Sci Tsunami Hazards (25):13:. https://doi.org/10.3130/aijt.13.337340

Paris R, Bravo JJC, González MEM et al (2017) Explosive eruption, flank collapse and megatsunami at Tenerife ca. 170 ka. Nat Commun 8 https://doi.org/10.1 038/ncomms15246

Park S, Van de Lindt JW, Gupta R et al (2012) Method to determine the locations of tsunami vertical evacuation shelters. Nat Hazards 63(2):891-908. https:// doi.org/10.1007/s1 1069-012-0196-3

Pasquarè G, Francalanci L, Garduno VH et al (1993) Structure and geologic evolution of the Stromboli volcano, Aeolian Islands, Italy. Acta Vulcanol 3:7989

Péroche M (2016) La gestion de crise tsunami dans la Caraïbe : contribution géographique aux dispositifs d'alerte et d'évacuation des populations. Thèse de doctorat, p 407

Péroche M, Leone F, Gutton R (2014) An accessibility graph-based model to optimize tsunami evacuation sites and routes in Martinique, France. Adv Geosci 38:1-8 https://doi.org/10.5194/adgeo-38-1-2014

Rai News (2019) Stromboli, esplosioni dal cratere: un morto e un ferito. Alcuni turisti scappano in mare, http://www.rainews.it/dl/rainews/articoli/stromboliesplosioni-cratere-turisti-mare-3eb39bbb-bb3a-42aa-a564-04c9dba610e4.html. Accessed 30 Sept 2020
Roberto A, Bertagnini A, Pompilio M, Bisson M (2014) Pyroclastic density currents at Stromboli volcano (Aeolian Islands, Italy): a case study of the 1930 eruption. Bull Volcanol 76:. https://doi.org/10.1007/s00445-014-0827-5(6)

Sahal A (2011) Le risque tsunami en France: contributions méthodologiques pour une évaluation intégrée par scénarios de risque. Thèse de doctorat, p 315

Sahal A, Frédéric L, Péroche M (2013) Complementary methods to plan pedestrian evacuation of the French Riviera's beaches in case of tsunami threat: graph-and multi-agent-based modelling. Nat Hazards Earth Syst Sci 13(7):1735-1743. https://doi.org/10.5194/nhess-13-1735-2013

Scheer S, Gardi A, Guillande R et al (2011) Handbook of tsunami evacuation planning - SCHEMA (scenarios for Hazard-induced emergencies management), project $n^{\circ} 030963$, specific targeted research project, space priority. Publications Office of the European Union

Smart GM, Crowley KHM, Lane EM (2016) Estimating tsunami run-up. Nat Hazards 80(3):1933-1947. https://doi.org/10.1007/s11069-015-2052-8

Tibaldi A (2001) Multiple sector collapses at stromboli volcano, Italy: how they work. Bull Volcanol 63(2-3):112-125. https://doi.org/10.1007/s004450100129

Tinti S, Armigliato A (2003) The use of scenarios to evaluate the tsunami impact in southern Italy. Mar Geol 199(3-4):221-243. https://doi.org/10.1016/S002 5-3227(03)00192-0

Tinti S, Bortolucci E, Romagnoli C (2000) Computer simulations of tsunamis due to sector collapse at Stromboli, Italy. J Volcanol Geotherm Res 96(1-2):103128. https://doi.org/10.1016/S0377-0273(99)00138-9

Tinti S, Manucci A, Pagnoni G, Armigliato A, Zaniboni F, (2005) The 30 December 2002 landslide-induced tsunamis in Stromboli: sequence of the events reconstructed from the eyewitness accounts. Natural Hazards and Earth System Sciences 5:763-775

Tinti S, Maramai A, Armigliato A, Graziani L, Manucci A, Pagnoni G, Zaniboni F (2006a) Observations of physical effects from tsunamis of December 30, 2002 at Stromboli volcano, southern Italy. Bull Volcanol 68(5):450-461. https://doi. org/10.1007/s00445-005-0021-x

Tinti S, Pagnoni G, Zaniboni $F$ (2006b) The landslides and tsunamis of the 30th of December 2002 in Stromboli analysed through numerical simulations. Bull Volcanol 68(5):462-479. https://doi.org/10.1007/s00445-005-0022-9

Wang WL, Liu SB, Lo SM, Gao L (2014) Passenger ship evacuation simulation and validation by experimental data sets. Proc Eng 71:427-432 https://doi.org/1 0.1016/j.proeng.2014.04.061

Watcharong C, Chuckpaiwong B, Mahaisavariya B (2005) Orthopaedic trauma following tsunami: experience from Phang Nga, Thailand. J Orthop Surg (Hong Kong) 13(1):1-2. https://doi.org/10.1177/230949900501300101

Weidmann U, Kirsch U, Schreckenberg M (eds) (2014) Pedestrian and evacuation dynamics 2012. Springer International Publishing, p 1424

Wood N, Jones JM, Yamazaki Y, Cheung KF, Brown J, Jones JL, Abdollahian N (2019) Population vulnerability to tsunami hazards informed by previous and projected disasters: a case study of American Samoa. Nat Hazards 95(3):505528. https://doi.org/10.1007/s11069-018-3493-7

\section{Publisher's Note}

Springer Nature remains neutral with regard to jurisdictional claims in published maps and institutional affiliations.

Ready to submit your research? Choose BMC and benefit from:

- fast, convenient online submission

- thorough peer review by experienced researchers in your field

- rapid publication on acceptance

- support for research data, including large and complex data types

- gold Open Access which fosters wider collaboration and increased citations

- maximum visibility for your research: over $100 \mathrm{M}$ website views per year

At $\mathrm{BMC}$, research is always in progress.

Learn more biomedcentral.com/submissions 